\title{
Sponge-Associated Bacteria: Isolation, Phylogenetic Analysis and Biotechnological Potential
}

\author{
Shreadah MA ${ }^{1 *}$, Abdel Monem MA ${ }^{2}$, Yakout $\mathrm{GA}^{2}$ and Aboul Ela $\mathrm{HM}^{1}$ \\ ${ }^{1}$ Department of Marine biotechnology and natural products (MBNP) Laboratory, Egypt \\ ${ }^{2}$ Department of Biochemistry, Faculty of Science, Egypt
}

*Corresponding author: Shreadah MA, Department of Marine biotechnology and natural products (MBNP) Laboratory, the National

Institute of Oceanography and Fisheries, Alexandria, Egypt

\section{ARTICLE INFO}

Received: 慧 February 14, 2019

Published: 㓞 February 28, 2019

Citation: Shreadah MA*, Abdel Monem MA, Yakout GA, Aboul Ela HM. SpongeAssociated Bacteria: Isolation, Phylogenetic Analysis and Biotechnological Potential. Biomed J Sci \& Tech Res 15(2)-2019. BJSTR. MS.ID.002682.

Keywords: Sponge Associated Bacteria; Phylogenetic Analysis; Bioactive Metabolite

\section{ABSTRACT}

Marine sponge Hyrtios erectus is a source of numerous toxic secondary metabolites, which are considered as products of the symbiotic species associated with the sponge. Sponge-associated bacteria have great potential in developing marine pharmaceutical industry since they are capable of synthesizing numerous bioactive metabolite compounds. This study aimed to isolate the associated bacteria, characterize their different secondary metabolite, and investigate their potential antioxidant and cytotoxicity activities. Sponge was taxonomically identified as Hyrtios erectus. Moreover, taxonomic and phylogenetic analyses of the bacteria on the basis of $16 \mathrm{~S}$ rRNA gene sequences showed that the dominant two phyla were Firmicutes and proteobacteria. The results of HPLC analysis revealed that Chlorogenic acid, Coffeic acid, and 3,5-Dicaffeoyl quinic acid were the main phenolic compounds present in the HA-MS-22 [JX494759] crude extract, whereas Chlorogenic acid and 3,5-Dicaffeoyl quinic acid were present in the HA-MS-21 [JX494761] crude extract. Moreover, extract HA-MS-22 [JX494759] did not contain gallic but contained tannic. In the meantime, extract HA-MS-21 [JX494761] contained both gallic and tannic acids. The highest level of total phenolic contents was shown in extracts HA-MS-22 (3.702 $\pm 0.10 \mathrm{mg}$ gallic equivalent $/ \mathrm{ml}$ ).

Whereas, the lowest value was shown in extract HA-MS-23 $(3.015 \pm 0.045 \mathrm{mg}$ gallic equivalent $/ \mathrm{ml})$. Significantly high concentration of total flavonoids $(11.16 \pm 0.46 \mathrm{mg}$ catechin equivalent $/ \mathrm{ml}$ ). were measured in the ethyl acetate JX494761 extract. The JX494759 crude extract contained also considerably high contents of total flavonoids $(7.61 \pm 0.003 \mathrm{mg}$ catechin equivalent $/ \mathrm{ml})$. Carotenoid compounds significantly varied among the two bacterial extracts; the highest total carotenoid concentration was shown in extract HA-MS-22 $(0.048 \mu \mathrm{g} / \mathrm{ml})$. Whereas, lower values were shown in extracts JX494761 $(4.098 \mu \mathrm{g} / \mathrm{ml})$. In the meantime, GC/MS profiling for the ethyl acetate extract of the studied sponge-associated bacteria revealed the presence of various phytochemical compounds having different biological activities. Results of FTIR spectroscopic studies have revealed the presence of various chemical compounds. The presence of $\mathrm{O}, \mathrm{N}, \mathrm{C}, \mathrm{Br}, \mathrm{P}, \mathrm{Cu}, \mathrm{K}, \mathrm{Cl}, \mathrm{Br}, \mathrm{S}$, $\mathrm{Mg}, \mathrm{Na}, \mathrm{Al}, \mathrm{Si}$ elements in the bacterial extracts marks their usage in therapeutic purposes and may remark the tested bacterial extracts in the current study as promising bioactive materials. IC50 values of the antioxidant activity of the tested two extracts JX494759 and JX494759 were 1.126 and $0.9591 \mathrm{mg} / \mathrm{ml}$ using DPPH assay and $9.43 \pm 0.021$ and $7.58 \pm 0.12$ using NO assay, respectively.

Moreover, potent antioxidant activity using ABTS + assay with percentages inhibition of IC50 = 11.17 and $3.83 \mathrm{mg} / \mathrm{ml}$ for JX494759 and JX494759, respectively. In the present study highly significant total antioxidant capacity values were also obtained by using phosphomolybdenum. The high potency of these isolates is mainly attributed to the presence of various classes of potentially active secondary metabolites detected in them. Indeed phenols, tannins, and alkaloids identified in the tested extracts have been reported to possess antioxidant and anticancer activities. The relative wide range of these 
biologically properties may results from the individual or from the combined modes of action of compounds belonging to the identified groups of constituents. The cytotoxicity screening studies revealed that the maximum cell growth inhibitory effects of bacterial crude extracts against the tested cancer cell lines; HepG2; HCT and MCF-7 were found to be $10.6,8.4$, and $8.5 \mu \mathrm{g} / \mathrm{ml}$, respectively for JX494759. On the meantime the maximum cell growth inhibitory effects of JX494761 bacterial crude extract was found to be 46.8, 37.3, and $13.9 \mu \mathrm{g} / \mathrm{ml}$, respectively for these cell lines. These results were confirmed by a protein kinase inhibition specialized screening revealing an inhibition activity of $94.44 \pm 1.24$ and $76.85 \pm 1.03 \%$ for HA-Ms-22 and HA-Ms-21.

\section{Introduction}

Marine sponges (phylum Porifera) are among the most ancient multicellular animals (metazoans). Sponges have long been known as a source for natural products of pharmaceutical and medical relevance [1]. The Red Sea sponges have been the focus of much recent interest [2-9] because they form close associations with a wide variety of microorganisms such as viruses, bacteria, archaea, fungi, protozoa,...etc. This complex micro biota makes marine sponges of particular interest to microbial ecology studies and also offers a potentially invaluable source of novel genes and gene products for biotechnological applications [10]. Spongeassociated microorganisms within their mesophyll matrix can make up 35-60\% of the total sponge mass [11]. Kefalas et al. [12] found that bacterial load was greater in sponge extract than in proximal sea water, reflecting the sponge ability to concentrate bacteria in its body. Sponge symbiont microorganisms are known capable of synthesizing numerous bioactive compounds with unique, complex and different structure compared with terrestrial microorganisms [13]. Nowadays, it is known that marine sponges and their associated microorganisms are economically important because they produce the most active bioactive compounds that are potentially useful for human in pharmaceutical industry sector, for instance as antimicrobial, antifungal, antioxidant, anticancer and anti-inflammatory agents $[14,15]$.

Bioactive compounds mostly found in sponge symbiont microorganisms are generally derived from alkaloids, terpenes, terpenoids and peptides [16]. These bacteria are widely reported to be highly potential as the producer of antimicrobial bioactive compound [17]. Antioxidant compounds have an important role in improving human health. The compounds can decrease the risk of multiple chronic degenerative diseases, for instance gastrointestinal infection, cancer, Alzheimer, cataract and coronary heart disease. Nowadays, alternatives of natural antioxidant compounds are sought and developed to obtain compound which is specific and has better activity. Marine microorganisms have incredible abilities as producers of compounds having anti-cancer activity and secondary metabolites used against different diseases. However, despite their tremendous bioactive potential, marine microorganisms have not been given the attention they actually deserve [18-20]. In this study, the isolation, phylogenetic analysis and biological activity of microbial community from the Red Sea Sponge Hyrtios erectus was investigated. The main objective of the present study are (1) molecular level identification of the isolated sponge-associated bacteria and (2) to explore secondary metabolite of bacteriaassociated Hyrtios erectus from the Red Sea and to characterize their potential as bioactive compounds, specifically those which act as antioxidant and anticancer.

\section{Materials and Methods \\ Sponge Collection}

Sponge samples were collected in May, 2010from four species were collected by SCUBA diving in the Red Sea (Figure 1). Three samples were collected from El-Gouna region at depth $1.5 \mathrm{~m}$ (GPS: N: 2722 39.98, E: 3340 58.95). One sample was collected from the National Institute of Oceanography and Fisheries station, Hurghada at depth 2m (GPS: N: 2717 07.45, E: 3346 26.50). The physical, chemical, and biological characteristics of the Red Sea marine environment have been very recently extensively investigated $[2-9,21-42]$. Samples were cut from the sponge with a dive knife while wearing latex gloves and individual pieces were transferred to separate plastic sample collection bags, brought to the surface, maintained at ambient seawater temperature and transported to the laboratory in the same day of collection. Sponge specimens were rinsed in sterile seawater, cut into pieces of ca. $1 \mathrm{~cm} 3$, and then thoroughly homogenized in a sterile mortar with 10 volumes of sterile seawater. The supernatant was diluted in ten-fold series $(10-1,10-2,10-3)$ and subsequently plated out on agar plates.

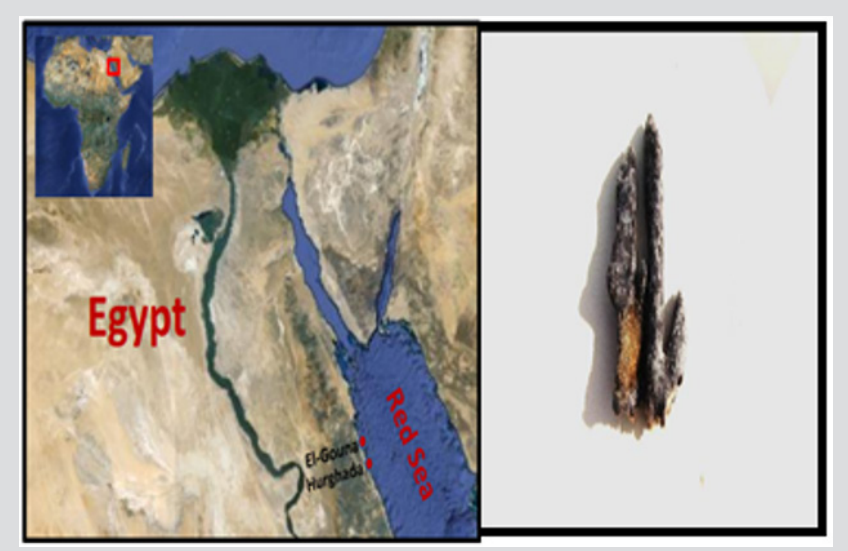

(A)

(B)

Figure 1: Map of Egypt showing the sampling sites at

a. Hurghada of the Red Sea coast and

b. the Red Sea Hyrtios erectus sponge.

Taxonomic Identification and Processing of the Sponge Sample

The sponge sample was taxonomically identified by Prof. Rob. W. M. van Soest, at the Institute for Systematic and Ecology, the 
University of Amsterdam, Amsterdam, Netherlands. A voucher fragment of the sponge was incorporated in the collections of the Zoological Museum of Amsterdam, now part of the Netherlands Centre for Biodiversity Naturalis (NCB Naturalis) at Leiden, The Netherlands, under registration number ZMA Por. 22535. Sponge was transferred to plastic bags containing sea-water and transported to the laboratory. Sponge specimen were rinsed in sterile seawater. Fresh specimen of each sponge was used for isolation of the sponge-associated bacteria. A section of sponge was immediately used to culture the sponge associated bacteria. Another section of sponge was immediately frozen on dry ice and stored at $-80{ }^{\circ} \mathrm{C}$. The sponge tissue was then freeze-dried prior to DNA extraction.

\section{Isolation of Sponge Associated Bacteria}

Two growth media were prepared to isolate a wide range of the sponge associated bacteria; Marine Agar [43] and ISP medium 2 [44] served as general rich media to grow many heterotrophic marine bacteria. All media were sup-plemented with $0.2 \mu \mathrm{m}$ pore size filtered cycloheximide $(100 \mu \mathrm{g} / \mathrm{mL})$, nystatin $(25 \mu \mathrm{g} / \mathrm{mL})$ and nalidixic acid $(25 \mu \mathrm{g} / \mathrm{mL})$. Cycloheximide and nystatin inhibit fungal growth, while nalidixic acid inhibits many fast-growing Gram-negative bacteria [45]. All media contained Difco Bacto agar $(18 \mathrm{~g} / \mathrm{L})$ and were prepared in $1 \mathrm{~L}$ artificial sea water $(\mathrm{NaCl} 234.7$ g, $\mathrm{MgCl} 2 \cdot 6 \mathrm{H} 2 \mathrm{O} 106.4$ g, Na2SO4 39.2 g, CaCl2 11.0 g, NaHCO3 1.92 g, KCl 6.64 g, KBr 0.96 g, H3BO3 0.26 g, SrCl2 0.24 g, NaF 0.03 g and ddH2O to $10.0 \mathrm{~L}$ ) (Lyman and Fleming, 1940). The inoculated plates were incu-bated at $28^{\circ} \mathrm{C}$ for 5 - 10 days. Distinct colony morpho-types were picked and re-streaked until visually free of contaminants. Isolates were inoculated into liquid media ISP medium 2. The isolates were maintained on plates for short-term storage and long-term strain collections were set up in medium supplemented with $30 \%$ glycerol at $-80^{\circ} \mathrm{C}$ [46].

\section{Extract Preparation and Cytotoxic Activity Screening}

Bacterial isolates were cultured in $500 \mathrm{~mL}$ Erlenmeyer flasks containing $200 \mathrm{~mL}$ of ISP2 medium. The liquid cultures were grown for 7 - 14 days depending on their growth rate at $30^{\circ} \mathrm{C}$ while shaking at $150 \mathrm{rpm}$. Crude extracts were prepared from whole cultures; containing cells and broths by ethyl acetate equal volume/three times, evaporated, lyophilized and dissolved in $1: 1 \mathrm{v} / \mathrm{v}$ DMSO $/ \mathrm{H} 2 \mathrm{O}$ and kept at $4^{\circ} \mathrm{C}$ until use for cytotoxic assay. The MTT (3-(4,5Dimethylthiazol-2-yl)-2,5-diphenyl tetrazolium bromide) assay which Measuring the mitochondrial re-ductase enzyme activity of viable cells that Could reduce MTT to formazan, giving a purple color, was used for screening the cytotoxicity of the bacterial extracts [47]. The cytotoxic activity of the microbial crude extracts was determined against three established cancer cell lines; MCF-7, HepG2 and HCT cells. Based on the values of the $\mathrm{IC}_{50}$, the most potent four bacterial extracts which exhibited the lowest $\mathrm{IC}_{50}$ were chosen for further study of their phylogenetic analysis and identification.

\section{Molecular Identification of the Bacterial Isolates Genomic DNA Extraction}

Bacterial DNA was extracted using QIAgen DNAesy Blood and Tissue Kit (Cat. \# 69506), following manufacturer's guidelines:

\section{Polymerase Chain Reaction (PCR) Amplification of 16S rRNA}

Following extraction of genomic DNA, polymerase chain reaction (PCR) was carried out in order to amplify the $16 \mathrm{~S}$ rRNA gene, the primers used to amplify the 16S rRNA gene were two universal bacterial primers: Forward primer $27 \mathrm{f}$ (5'-AGAGTTTGATCCTGGCTCAG-3') and reverse primer $1492 \mathrm{r}$ (5'-GTTACCTTGTTACGACTT-3') designed to target the conserved regions of the $16 \mathrm{~S}$ rRNA gene [48].

\section{DNA Sequencing and Constructing the Phylogenetic Tree}

The isolated bacteria were first identified to the species level by PCR amplification of the 16S rRNA gene, BLAST analysis, and comparison with sequences in the GenBank nucleotide database. Specifically, the 16S rRNA gene from the strain was amplified using universal primers 27f (5'-AGAGTTTGATCCTGGCTCAG-3') and 1492r (5'-GGTTACCTTGTTACGACTT-3'). The PCR conditions used were the same as those described previously [49]. The PCR products were purified and sequenced by the GATC-Biotech. Company (Tübingen, Germany). The sequences were compared with known sequences in the GenBank nucleotide database and the species level was identified as the nearest phylogenetic neighbor with $98 \%-100 \%$ similarity [1]. Sequence alignment and phylogenetic analysis were performed using the Mega-5 software package [50]. Tree construction was conducted using neighbor joining algorithm (Jukes-Cantor correction) with bootstrap values based on 1000 replications. The 16S rRNA gene sequences the isolates were deposited in GenBank under the accession Numbers indicated in brackets: HA-MS-22 [JX494759] and HA-MS-21 [JX494761].

\section{Chemical Investigations of the Bacterial Isolates Analytical HPLC analysis}

$20 \mu \mathrm{l}$ sample extract was analyzed with a Exclipse XDB C18 (5 $\mu \mathrm{m}, 4.6 * 150 \mathrm{~mm}$ ) column using a mobile phase consisting $1 \%(\mathrm{v} / \mathrm{v})$ formic acid in aqueous solution: acetonitrile: 2-propanol (70:22:8), $\mathrm{pH} 2.5$; flow rate: $0.75 \mathrm{ml} / \mathrm{min}$, temperature: $30 \mathrm{oC}$, UV detection at $320 \mathrm{~nm}$; Agilent technologies 1200 series. Phenolic compound concentrations were calculated from the standard curves of the supplied phenolic standards exist in the data library

\section{Gas Chromatography- Mass Spectrophotometer (GC-MS) Analysis}

Analysis was conducted using Gas Chromatography-Mass Spectrophotmeter; GC-MS (Trace DSQII MS). MS conditions were as follows: Detector mass spectrometer voltage $70 \mathrm{eV}$ and its source temperature was $300 \mathrm{o} \mathrm{C}$. The injector temperature was $240^{\circ} \mathrm{C}$ and the split less mode $0.5 \mu \mathrm{L}$ injection. The HP 55\% dimethyl-95\% dimethyl tertiary-butyl non-polar column was performed with length $30 \mathrm{~cm} \times 0.25 \mathrm{~mm}$, coating thickness film $0.25 \mu \mathrm{m}$. The oven was adjusted at $80^{\circ} \mathrm{C}$ for $1 \mathrm{~min}$ and initial time $1.5 \mathrm{~min}$ with $40^{\circ} \mathrm{C}$ which ended by a final temperature of $300^{\circ} \mathrm{C}$ and $4 \mathrm{~min}$ hold time where the total run time was $15 \mathrm{~min}$. The compounds were identified by comparison with the standards, and also matched with the in-built libraries. The components were identified by comparing their retention times with those of authentic samples, as well as by comparing their mass spectra with those of Wiley 
275 Library [51]. Quantitative data were obtained by the peak normalization technique using integrated FID response.

\section{Infrared Analysis (FT-IR)}

Using Perkin-ELMER1430 infrared spectrophotometer, the molecular structure of the extracts was partial identified. Separated spots of each compound were collected by scratching and dissolved in $1 \mathrm{ml}$ ethyl acetate and lyophilized then small discs made from the mixture of about $1 \mathrm{mg}$ of the lyophilized material and $300 \mathrm{mg}$ of pure and dry $\mathrm{KBr}$ were subjected to IR-spectroscope. The measurement were carried out at infrared spectra between 400-4000nm.

\section{Elemental Analysis}

The bacterial extracts were subjected to the elemental analysis using Scanning Electron Microscope (SEM) with an energy dispersive x-ray spectrophotometer (EDX). This was carried out at the Regional Center for Mycology and Biotechnology, Al-Azhar University, Egypt.

\section{Determination of Total Phenolic Contents}

Total phenolic compounds in the fungal extracts were determined by the method of Taga et al. [52]. One hundred microliters Folin-Ciocalteau reagent $(50 \%, v / v)$ in distilled water and $2 \mathrm{ml}$ sodium carbonate $(2 \%, \mathrm{v} / \mathrm{v})$ in distilled water were added and mixed well with $100 \mu \mathrm{l}$ of fungal extract. After $2 \mathrm{~h}$ incubation at RT, the absorbance of the resulting blue color solution was measured at $750 \mathrm{~nm}$. Different concentrations $(0-0.9 \mathrm{mg} / \mathrm{ml})$ of standard gallic acid were used and processed similarly as sample. The concentration of total phenolic in bacterial extracts was determined as mg gallic acid equivalent in $1 \mathrm{ml}$ of the extract using the standard curve of the gallic acid.

\section{Determination of Total Flavonoid Contents}

Total flavonoid content was determined by a colorimetric method of Zhishen et al. [53]. A $0.25 \mathrm{ml}$ of fungal extract or (+)-catechin standard solution was mixed with $1.25 \mathrm{ml}$ of distilled water, followed by the addition of $0.75 \mathrm{ml}$ of $5 \%$ sodium nitrite solution. After $6 \mathrm{~min}, 0.15 \mathrm{ml}$ of $10 \%$ aluminum chloride solution was added and the mixture was made up to $2.5 \mathrm{ml}$ with distilled water and well mixed. The absorbance was measured immediately at $510 \mathrm{~nm}$ using a spectrophotometer. The results were expressed as mean $\mathrm{ml}$ of $(+)$-catechin equivalents.

\section{Bioactivity Screening of the Bacterial Extracts}
A) Anticancer activity screening
B) Cytotoxicity against cancer cell lines

Cytotoxicity Evaluation Using Viability Assay: For cytotoxicity assay, the cells were seeded in 96-well plate at a cell concentration of $1 \times 104$ cells per well in $100 \mu \mathrm{l}$ of growth medium. All experiments were carried out in the triplicate. The cell cytotoxic effect of each tested compound was calculated [54,55].

Protein Kinase Inhibitory Effect: Protein kinase inhibitory effect of the tested bacterial extract was determined by Universal Tyrosine Kinase Kit; Takara (CAT \# MK410) [http://www.takara. co.kr/file/manual/pdf/MK410_e.pdf] following the manufacturer's instructions with some modifications.

\section{In Vitro Antioxidant Capacity Screening}

A) Nitric Oxide Scavenging Activity: The extent of inhibition of nitric oxide radical generation in vitro was followed as per the method reported by Green et al. [56].

B) Diphenyl- $\alpha$-Picrylhydrazyl (DPPH) radical scavenging assay: DPPH radical scavenging assay (Figure 2) of the extracts was performed by using modified previously established methodology by Blois [57] and Amarowicz et al. [58]. Assays were performed in flat bottom polystyrene 96 well microtiter plates. To $100 \mu \mathrm{L}$ of each sample $(1-6 \mathrm{mg} / \mathrm{ml})$ in EtOH $25 \mu \mathrm{L}$ DPPH $(1 \mathrm{mM})$ in ethanol was added. The resultant mixture was briefly shaken and maintained at room temperature, in the dark for $30 \mathrm{~min}$. At the end of this period the absorbance (A) of the mixture was measured at $490 \mathrm{~nm}$, using Microplate reader spectrophotometer. Scavenging ratio of DPPH assay was calculated as follows:

\%scavenging $=[($ A control - A sample $] /$ A control $)] \times 100$

C) ABTS+ Scavenging Effects: The antioxidant effect of the leaf extracts was studied using ABTS (2,2'-azinobis3-ethylbenzthiazoline-6-sulphonic acid) radical cation decolourisation assay according to the method of Shirwaikar et al. [59].

Inhibition $(\%)=($ Control - test $) /$ Control $\times 100$

All Measurements were expressed as Trolox equivalents. Standard regression line for Trolox was used to calculate TEAC values.

D) Phosphomolybdenum Assay: This assay is a spectroscopic method for the quantitative determination of antioxidant capacity, through the formation of phosphomolybdenum complex.

\section{Results and Discussion}

\section{Recovery of the Bacterial Isolate from the Culture Media}

Culture based techniques and 16S rRNA based molecular technique were employed to characterize the bacterial communities associated with the Red Sea Hyrtios erectus sponge having promising secondary metabolite profiles. Based on the morphological characteristics and uniqueness, a bacterial pure isolate was selected from sponge Hyrtios erectus. The bacterial isolates were given codes prior to identification (HA-MS -22) and (HA-MS -21).

\section{Molecular identification of the Bacterial Isolate}

DNA Base Composition and Sequencing of The 16s Ribosomal DNA (rDNA): The 16S rRNA genes were amplified by using general bacterial primers. The forward primer $(27 \mathrm{f}$ 5'-CCAGAGTTTGATCCTGGCTCAG-3') and reverse primer (1492 r 5'-TAC CTT GTT ACG ACT T-3') were used for amplification of $16 \mathrm{~S}$ rRNA genes the studied bacterial isolate. The amplified 16S rRNA gene was $1.5 \mathrm{~kb}$.

Sequence Alignments and Phylogenetic Inference: The bacterial isolate was identified using a molecular approach. The results showed that the 16S rRNA genes belonged mainly 
to the phyla proteobacteria. The sequence were deposited in the GenBank database. Accession numbers JX494759 and JX494761 corresponded to the strains HA-MS -22 and HA-MS-21 (Table 1). For the Hyrtios erectus sponge sample, bacterial PCR product was sequenced and phylogeneticaly analyzed (Figures $2 \& 3$ ). The present study cleared out that the identified bacterial species were Firmicutes and Proteobacteria (especially Gamma- Proteobacteria). The phylum Proteobacteria and the phylum Firmicutes are always found in different sponges having varied effects on sponge hosts and they may produce bioactive secondary metabolites $[60,61]$.

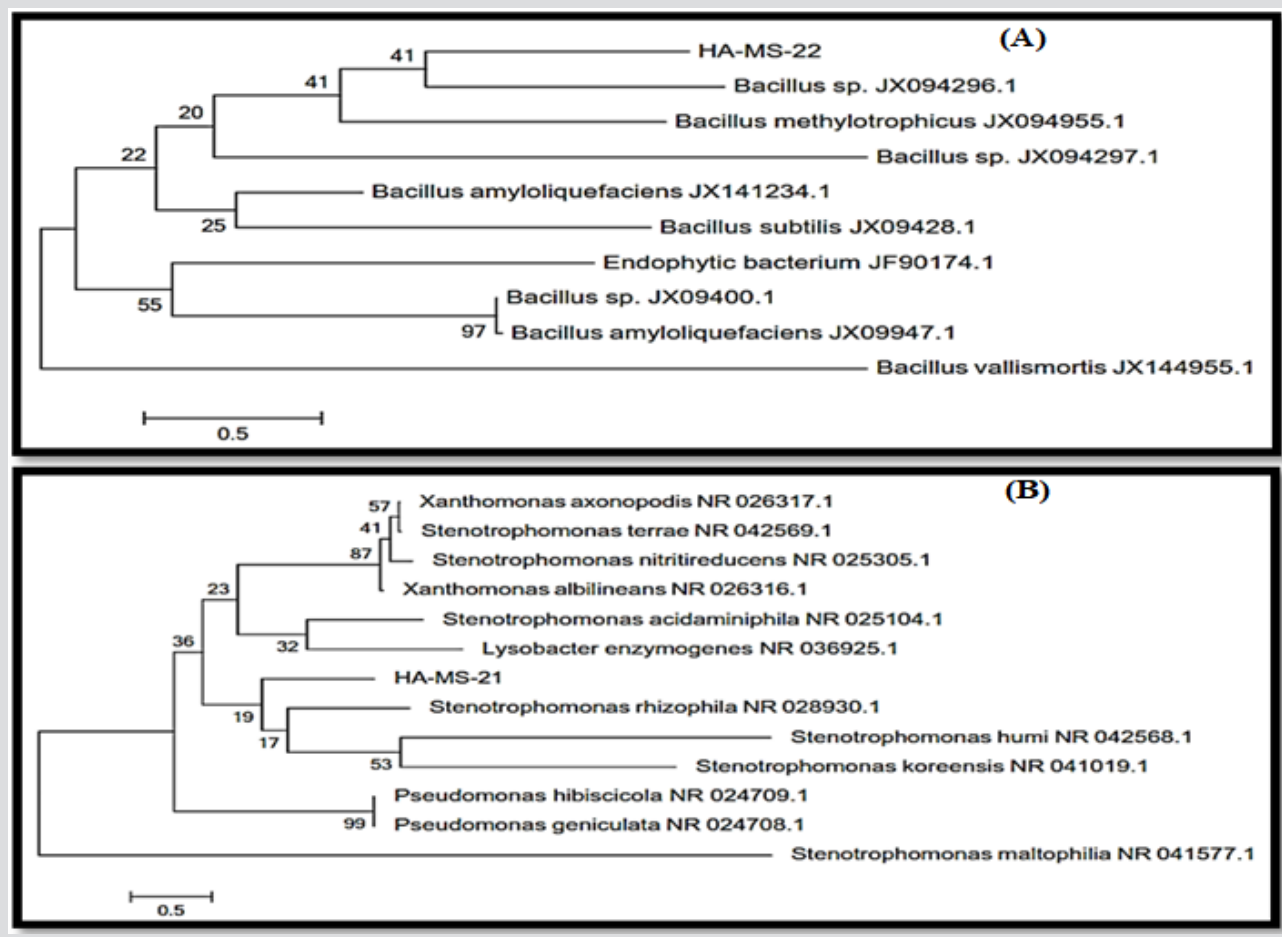

Figure 2: Molecular Phylogenetic analysis of the bacterial isolates (A) JX494759 and (B) JX494761 by Maximum Likelihood method. The scale bar indicates 0.5 substitutions per nucleotide position.

(A)<smiles>O=C(O)c1cc(O)c(O)c(O)c1</smiles>

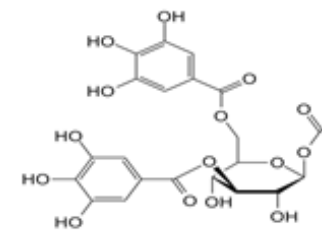

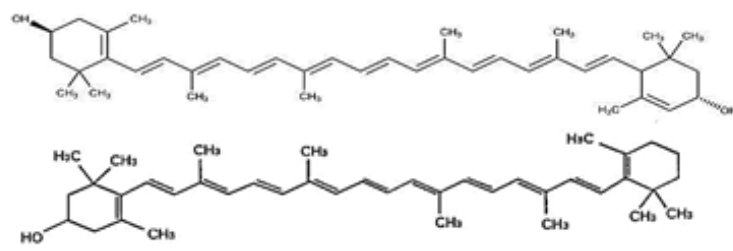

(E)<smiles>CC(C)CCCC(C)CCC1C(C)CCCC1(C)C</smiles>

(F)<smiles>Oc1cc(O)c2c(c1)OC(c1ccc(O)c(O)c1)C(O)C2</smiles>

(B)

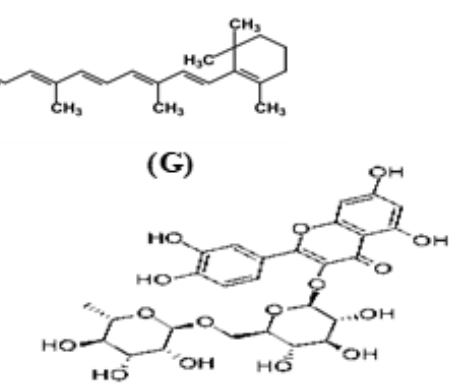

Figure 3: Structure of

a. Gallic acid, b. Tannic acid, c. Xanthophyll, d. $\beta$-cryptoxanthin, e. carotene, f. Catechin and g. Rutin. 
Table 1: Morphological characteristics and code numbers of the isolated bacteria from the sponge sample.

\begin{tabular}{|c|c|c|}
\hline Sponge & Isolate Code & Colony Morphology \\
\hline & & HA-MS-22 \\
Hyrtios erectus & HA-MS-21 & Orange yellow, flat, regular edge \\
\cline { 2 - 3 } & & Yellowish creamy, raised, regular edge \\
\hline HA-MS-22 [JX494759] & $\begin{array}{c}\text { Bacillus vallismortis. 16S ribosomal RNA, partial } \\
\text { sequence (NR_024696.1), 98\% }\end{array}$ & Firmicutes \\
\hline HA-MS-21 [JX494761] & $\begin{array}{c}\text { Stenotrophomonas humi. 16S ribosomal RNA, } \\
\text { partial sequence (NR_042568.1), 99\% }\end{array}$ & Proteobacteria \\
\hline
\end{tabular}

\section{Chemical Investigation of the Bacterial Extract}

Ethyl acetate extract of the two bacterial isolates were subjected to chemical profiling and characterization using HPLC, GC/MS, FTIR and elemental analysis techniques.

\section{Analytical HPLC Analysis}

The results obtained from HPLC analysis against a wide range of phytochemical standards revealed that there were considerable amounts of well-established bioactive compounds such as phenolic compounds, terpenoids and carotenoid compounds.

\section{Phenolic Compounds}

The obtained results from the analytical determination of reversed-phase (RP) HPLC against wide range of phytochemical standards revealed that the bacterial exhibited variable patterns

Table 2: Concentrations of phenolic compounds, gallic and tannic acids, total flavonoid compounds, carotenoid Catechin and Rutin, as well as flavonoid compounds. of phenolic compounds (Table 2). Chlorogenic acid, Coffeic acid, and 3,5-Dicaffeoyl quinic acid were the main phenolic compounds present in the JX494759 crude extract, whereas Chlorogenic acid and 3,5-Dicaffeoyl quinic acid were present in the X494761crude extract. Two of the most powerful structurally related phenolic compounds are Gallic and Tannic acids were also determined by the HPLC analysis for the tested bacterial extracts. Extract JX494759 did not contain gallic but contained tannic. In the meantime, extract JX494761 contained both gallic and tannic acids (Table 2). Tannic and gallic acids are two commonly phenolic acids that are structurally related. Tannic acid, a naturally occurring plant polyphenol, is composed of a central glucose molecule derivatized at its hydroxyl groups with one or more galloyl residues, whereas gallic acid is a trihydroxybenzoic acid, also known as 3,4,5-trihydroxybenzoic acid. It has been reported that reduced cisplatin induced functional and histological renal damage (Figure 2).

\begin{tabular}{|c|c|c|}
\hline \multirow{2}{*}{ Bioactive Compounds } & \multicolumn{2}{|c|}{ Extract } \\
\hline & JX494759 & JX494761 \\
\hline \multicolumn{3}{|l|}{ Phenolic contents $(\mu \mathrm{g} / \mathrm{ml}) \mathrm{a}$} \\
\hline Chlorogenic acid & 1.754 & 0.549 \\
\hline Coffeic acid & 1.764 & ND \\
\hline 3,5-Dicaffeoyl quinic acid & 3.046 & 3.558 \\
\hline Total & 6.564 & 4.098 \\
\hline Gallic acid (mg/ml)a & ND & 0.505 \\
\hline Tannic acid $(\mathrm{mg} / \mathrm{ml}) \mathrm{a}$ & 0.564 & 0.453 \\
\hline $\begin{array}{l}\text { Flavonoid compounds } \\
{\text { (mg gallic acid equivalent } / \mathrm{ml})^{\mathrm{b}}}^{\text {b }}\end{array}$ & $3.015 \pm 0.045$ & $3.702 \pm 0.10$ \\
\hline \multicolumn{3}{|l|}{ Carotenoids contents $(\mu \mathrm{g} / \mathrm{ml})^{\mathrm{a}}:$} \\
\hline \multirow[t]{2}{*}{ Xanthophyll } & ND & 0.132 \\
\hline & ND & ND \\
\hline$\beta$-carotene & 0.048 & 0.068 \\
\hline Total & 0.048 & 4.098 \\
\hline
\end{tabular}




\begin{tabular}{|c|c|c|}
\hline Flavonoids & 13.703 & 5.430 \\
Catechin (mg/ml)a & 0.649 & ND \\
\hline Rutin (mg/ml)a & $7.61 \pm 0.003$ & $11.16 \pm 0.46$ \\
\hline $\begin{array}{c}\text { Total flavonoid contents (mg catechin } \\
\text { equivalent/ ml)b }\end{array}$
\end{tabular}

\section{Total Phenolic Contents}

Highly significant quantities of phenolic contents were found in crude extracts as gallic in the two bacterial extracts (Table 2). Phenolic compounds comprise a broad class of natural products formed mainly by plants, but also microorganisms and marine organisms that have the capacity to form them. Nowadays the interest in these compounds has increased mainly due to their diverse chemical structure and wide biological activity valuable in the prevention of some chronic or degenerative diseases [62]. Furthermore, they suppressed the generation of ROS, lipid peroxidation, and oxidative stress in kidney tissues. These results indicated that both gallic and tannic acids exhibit nephroprotective effect and the possible mechanism of action by which they exert this effect could be due to their antioxidant properties and inhibition of arginase activity. However, tannic acid exhibited better nephroprotective potential than gallic acid which may be due to the glycosidation with a glucose moiety [63].

\section{Carotenoids Compounds}
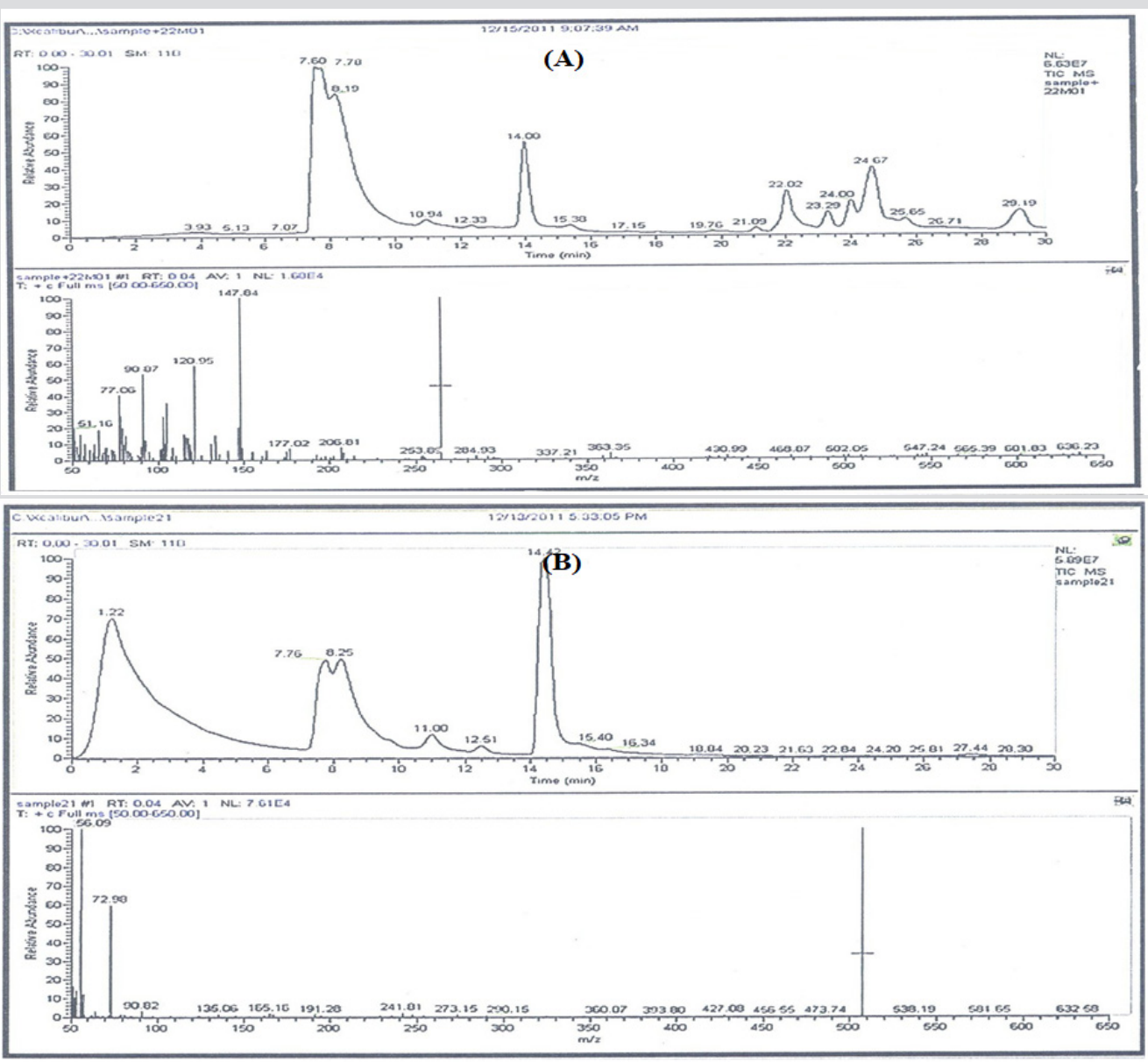

Figure 4: GC-MS patterns of the bacterial ethyl acetate extracts extract JX494759 and JX494761.

Carotenoid contents, namely, Xanthophyll, $\beta$-cryptoxanthin and $\beta$-carotene were the major carotenoid compounds investigated in the two bacterial extract (Figures $4 \& 5$ ) This group of compounds were reported to have considerable attention because of their wide biotechnological applications and, more importantly, due to their potential beneficial applications in the fields of human healthcare, food processing, pharmaceuticals and cosmetics [64,65]. It has been stated that marine microorganisms offer numerous advantages as natural sources of carotenoids: they usually have low nutritional requirements during their growth and cultivation, which reduces the production costs; the culture medium in which they grow contains moderate or high salt concentrations, which prevents contamination with other microorganisms, reducing the costs and facilitating the downstream processes; these microorganisms are also a source of rare carotenoids [66]. The present study cleared that the two tested bacterial isolates from Firmicutes and Proteobacteria associated with the Red Sea Hyrtios erectus sponge revealed the presence of $\beta$-carotene in the tested two extracts (Tables 2-4). Xanthophyll was present only in the JX494761 crude extract. On the other hand, the tested two bacterial extracts did not show any $\beta$-cryptoxanthin contents (Table 5). 


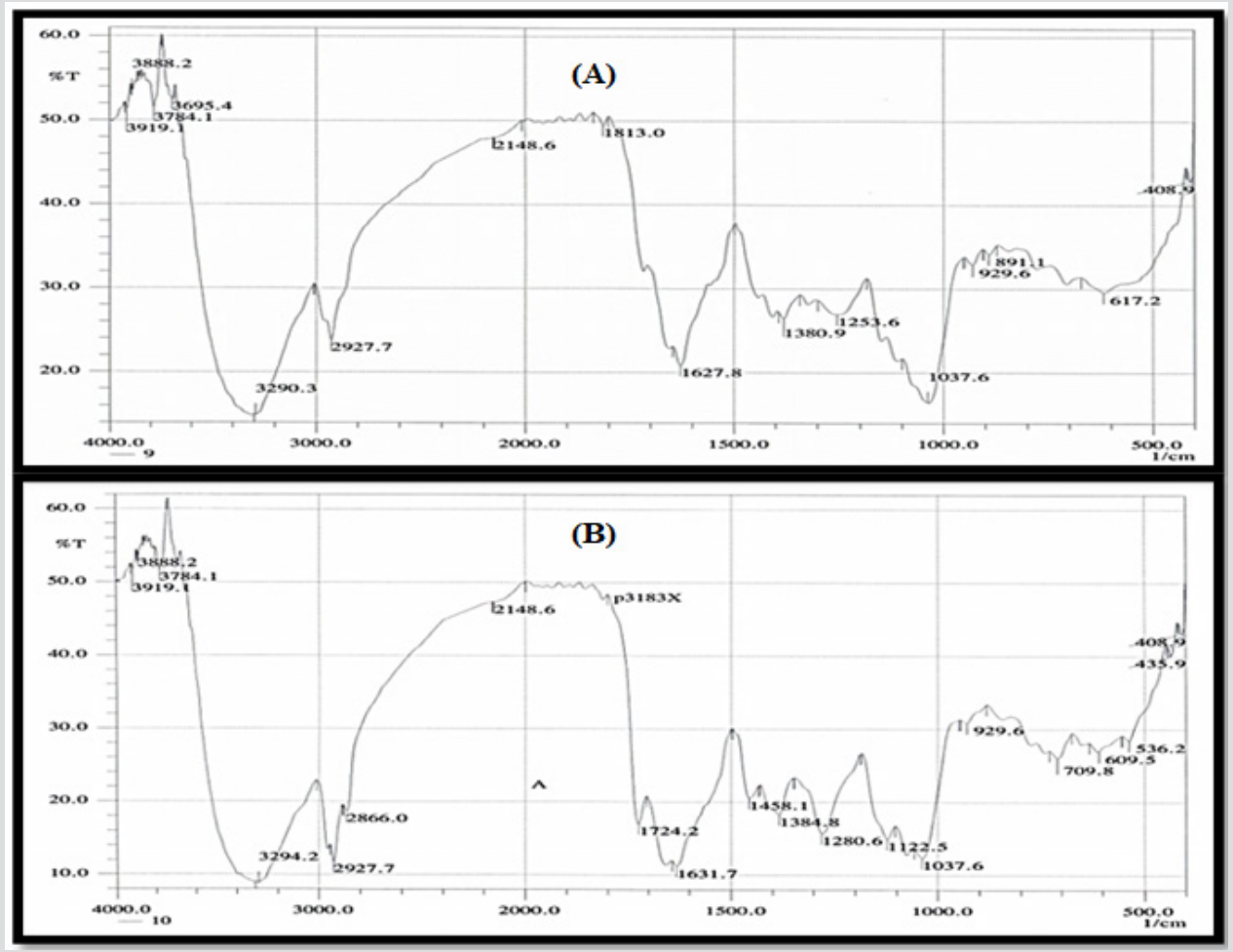

Figure 5: FTIR analysis of the ethyl acetate crude extracts JX494759 and JX494761.

Table 3: Bioactive compounds identified in the crude extracts (A) JX494759 and (B) JX494761 by GC-MS.

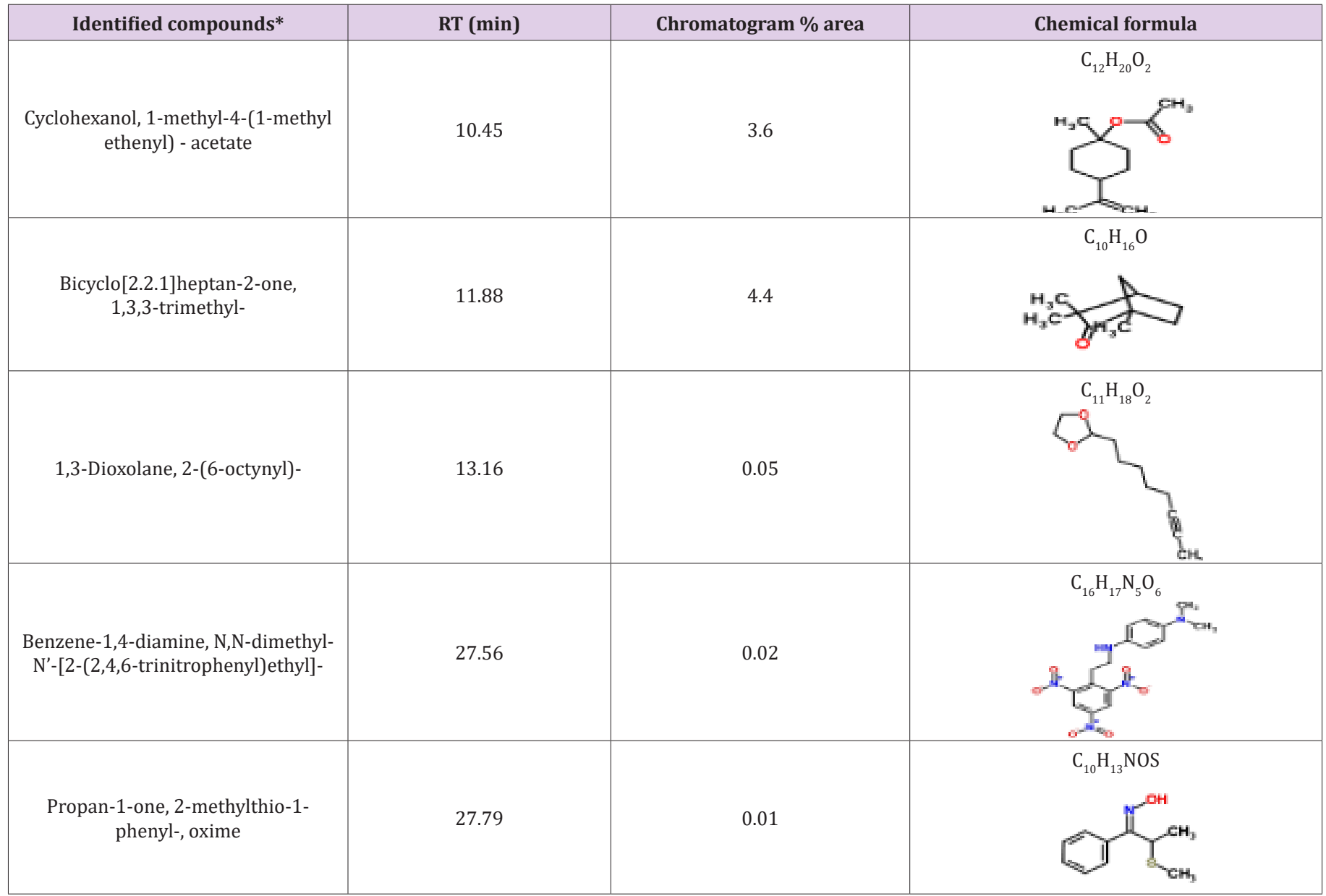




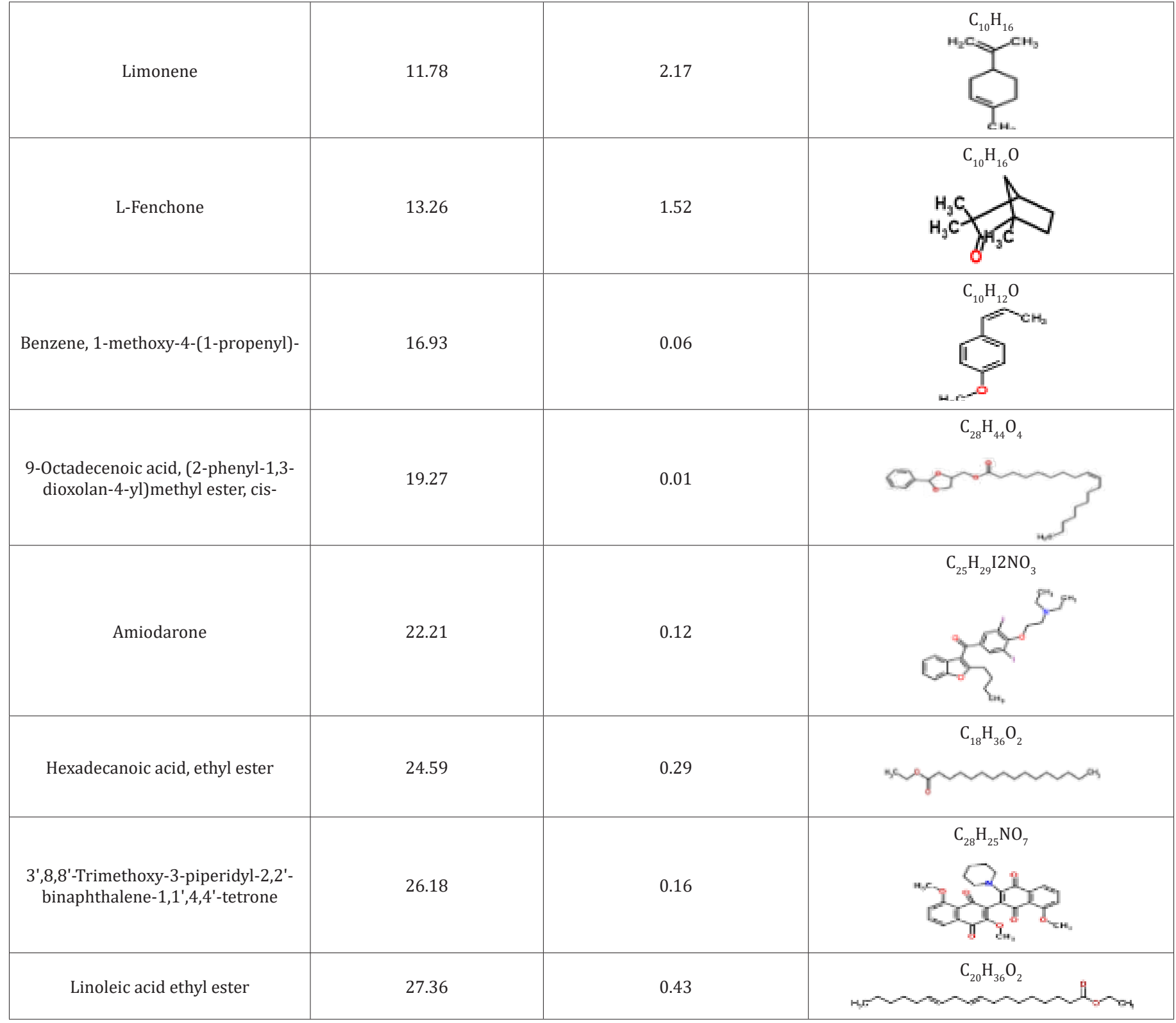

Table 4: Bioactive composition of the studied bacterial extracts obtained by GC/MS analysis and their bioactivity profiling.

\begin{tabular}{|c|c|c|c|c|c|c|}
\hline \multirow{2}{*}{ No. } & \multirow{2}{*}{ Compound } & \multirow{2}{*}{ Chemical nature } & \multicolumn{2}{|c|}{ Extract } & \multirow{2}{*}{ Bioactivity } & \multirow{2}{*}{ References } \\
\hline & & & JX494759 & JX494761 & & \\
\hline 1 & Limonene & $\begin{array}{l}\text { Monocyclic-mono- } \\
\text { terpene }\end{array}$ & & + & $\begin{array}{c}\text { Anticancer antioxidant, growth } \\
\text { supplement }\end{array}$ & [72] \\
\hline 2 & $\begin{array}{c}\text { Bicyclo[2.2.1] } \\
\text { heptan-2-one, } \\
\text { 1,3,3-trimethyl- }\end{array}$ & $\begin{array}{l}\text { Sesquiterpene } \\
\text { Hydrocarbons }\end{array}$ & + & & $\begin{array}{l}\text { Anti-inflammatory, anticancer, } \\
\text { antibacterial }\end{array}$ & [73] \\
\hline 3 & $\begin{array}{l}\text { Benzene, } \\
\text { 1-methoxy-4- } \\
\text { (1-propenyl)- } \\
\text { (Anethole) }\end{array}$ & Polyphenolic & & + & $\begin{array}{l}\text { Antibacterial, antifungal, } \\
\text { insecticidal, antihelmintic, } \\
\text { psychoactive effect }\end{array}$ & [74] \\
\hline 4 & $\begin{array}{l}\text { Hexadecanoic acid, } \\
\text { ethyl ester }\end{array}$ & $\begin{array}{c}\text { Aliphatic carboxylic } \\
\text { hudrocarbons (Fatty } \\
\text { acid esters) }\end{array}$ & & + & $\begin{array}{c}\text { Antibacterial, } \\
\text { antifungal, Antioxidant, } \\
\text { Hypocholesterolemic } \\
\text { Nematicide, Pesticide, Lubricant, } \\
\text { Antiandrogenic, Flavor, } \\
\text { Hemolytic 5-Alpha reductase } \\
\text { inhibitor }\end{array}$ & [75] \\
\hline 5 & $\begin{array}{l}\text { Linoleic acid ethyl } \\
\text { ester }\end{array}$ & $\begin{array}{c}\text { Aliphatic carboxylic } \\
\text { hudrocarbons (Fatty } \\
\text { acid esters) }\end{array}$ & & + & $\begin{array}{l}\text { Insecticide, pesticide, cosmetics } \\
\text { and personal care products }\end{array}$ & [76] \\
\hline
\end{tabular}




\begin{tabular}{|c|c|c|c|c|c|c|}
\hline 6 & $\begin{array}{l}\text { Cyclohexanol, } \\
\text { 1-methyl-4-(1- } \\
\text { methylethenyl)-, } \\
\text { acetate }\end{array}$ & Cyclic terpenoids & + & & Antifungal & {$[77]$} \\
\hline 7 & L-Fenchone & $\begin{array}{c}\text { Terpene } \\
\text { hydrocarbones }\end{array}$ & & + & $\begin{array}{l}\text { Antialzheimeran; LGR; } \\
\text { Counterirritant; JBH; FLavor; } \\
\text { FEMA 0.1-5; ARC; Perfumery; } \\
\text { M11; Secretolytic; BIS }\end{array}$ & [78] \\
\hline \multirow[t]{2}{*}{8} & $\begin{array}{l}\text { 9-Octadecenoic } \\
\text { acid, (2-phenyl- } \\
\text { 1,3-dioxolan-4-yl) } \\
\text { methyl ester, cis- }\end{array}$ & $\begin{array}{l}\text { Cyclopropane } \\
\text { derivative }\end{array}$ & & & Anaesthesic & [79] \\
\hline & & & & + & & \\
\hline 9 & $\begin{array}{l}\text { 1,3-Dioxolane, } \\
\text { 2-(6-octynyl)- }\end{array}$ & $\begin{array}{l}\text { Dioxolane derivative } \\
\text { (Cyclic peroxides) }\end{array}$ & + & & Antifungal, cytotoxic & {$[80,81]$} \\
\hline 10 & $\begin{array}{c}\text { Benzene- } \\
\text { 1,4-diamine, } \\
\text { N,N-dimethyl- } \\
\text { N'-[2-(2,4,6- } \\
\text { trinitrophenyl) } \\
\text { ethyl]- }\end{array}$ & Polycyclic alkaloides & + & & $\begin{array}{l}\text { Anticancer, antibacterial, } \\
\text { antifungal,, antiviral }\end{array}$ & {$[82]$} \\
\hline 11 & $\begin{array}{l}\text { Propan-1-one, } \\
\text { 2-methylthio-1- } \\
\text { phenyl-, oxime }\end{array}$ & & + & & Anticancer & [83] \\
\hline 12 & Amiodarone & Phenolics & & + & $\begin{array}{l}\text { Vasodilator agents, enzyme } \\
\text { inhibitors, anti-arrhythmia }\end{array}$ & {$[84]$} \\
\hline \multirow[t]{2}{*}{13} & $\begin{array}{c}\text { 3',8,8'-Trimethoxy- } \\
\text { 3-piperidyl-2,2'- } \\
\text { binaphthalene- } \\
\text { 1,1',4,4'-tetrone }\end{array}$ & Alkaloids & & & Antisickling & {$[85]$} \\
\hline & & & & + & & \\
\hline 14 & Estragole & Phenyl propene & + & + & $\begin{array}{c}\text { Anesthetic; Anticonvulsant; } \\
\text { Myorelaxant; }\end{array}$ & [86] \\
\hline
\end{tabular}

Table 5: Elemental analysis of the ethyl acetate extracts of the JX494759 and JX494761 bacterial isolate.

\begin{tabular}{|c|c|c|c|c|c|c|c|}
\hline \multicolumn{9}{|c|}{ JX494759 } & \multicolumn{4}{c|}{ JX494761 } \\
\hline \multicolumn{9}{|c|}{} & \multicolumn{1}{|c|}{ Extract } \\
\hline Element & Percentage (\%) & Element & Percentage (\%) & Element & Percentage (\%) & Element & Percentage (\%) \\
\hline $\mathrm{O}$ & 17.417 & $\mathrm{Cl}$ & 0.090 & $\mathrm{O}$ & 49.107 & $\mathrm{Cl}$ & 0.247 \\
\hline $\mathrm{C}$ & 36.933 & $\mathrm{~S}$ & 0.037 & $\mathrm{C}$ & 31.460 & $\mathrm{~S}$ & 0.510 \\
\hline $\mathrm{N}$ & 17.173 & $\mathrm{Mg}$ & $\mathrm{N} . \mathrm{D}$ & $\mathrm{N}$ & 15.943 & $\mathrm{Mg}$ & 0.100 \\
\hline $\mathrm{Br}$ & 18.013 & $\mathrm{Na}$ & $\mathrm{N} . \mathrm{D}$ & $\mathrm{Br}$ & 0.120 & $\mathrm{Na}$ & 0.953 \\
\hline $\mathrm{P}$ & $\mathrm{N.D.}$ & $\mathrm{Al}$ & $\mathrm{N} . \mathrm{D}$ & $\mathrm{P}$ & 0.513 & $\mathrm{Al}$ & 0.033 \\
\hline $\mathrm{Cu}$ & 0.153 & $\mathrm{Si}$ & $\mathrm{N} . \mathrm{D}$ & $\mathrm{Cu}$ & 0.163 & $\mathrm{Si}$ & 0.047 \\
\hline $\mathrm{K}$ & 10.190 & & & $\mathrm{~K}$ & 0.800 & & \\
\hline
\end{tabular}

\section{Flavonoid Compounds}

The presence of two flavonoid compounds was tested in the bacterial extracts; Catechin and Rutin (Figure 3). Rutin compound was below the detectable limit in extract JX494761. The highest catechin values were found in JX494759 extract (13.703 mg/ $\mathrm{ml})$. Rutin was detected also in the same extract $(0.649 \mathrm{mg} / \mathrm{ml})$ as shown in (Table 2). It can be seen from (Table 6) that the total flavonoids values showed high contents of flavonoid compounds in the ethyl acetate of JX494761 and JX494759.

Table 6: Total antioxidant of the examined two extracts using DPPH , Nitric oxide (NO) and phosphomolybdenum assays.

\begin{tabular}{|c|c|c|c|c|c|c|}
\hline \multirow{2}{*}{$\begin{array}{c}\text { Extract } \\
\begin{array}{c}\text { concentration } \\
\mathbf{( m g / m l )}\end{array}\end{array}$} & \multicolumn{2}{|c|}{ TEAC/mM equivalent Ascorbic acid* } & \multicolumn{2}{|c|}{ EAC/mM equivalent Ascorbic acid* } & \multicolumn{2}{|c|}{ TEAC/mM equivalent Ascorbic acid* } \\
\cline { 2 - 7 } & $\mathbf{J X 4 9 4 7 5 9}$ & $\mathbf{J X 4 9 4 7 6 1}$ & $\mathbf{J X 4 9 4 7 5 9}$ & $\mathbf{J X 4 9 4 7 6 1}$ & \multicolumn{1}{|c|}{ JX494759 } & JX494761 \\
\hline 30 & $93.71 \pm 0.01$ & $95.62 \pm 0.000$ & $52.52 \pm 0.024$ & $69.35 \pm 0.003$ & $7.434 \pm 0.001$ & $34.656 \pm 0.009$ \\
\hline 6 & $92.71 \pm 0.000$ & $94.92 \pm 0.01$ & $31.78 \pm 0.011$ & $40.56 \pm 0.024$ & $1.661 \pm 0.020$ & $6.363 \pm 1.980$ \\
\hline 1.2 & $92.58 \pm 0.02$ & $94.12 \pm 0.00$ & $30.19 \pm 0.001$ & $33.46 \pm 0.03$ & $1.39 \pm 0.002$ & $1.39 \pm 0.098$ \\
\hline 0.24 & $90.03 \pm 0.01$ & $93.07 \pm 0.01$ & $30.19 \pm 0.006$ & $31.31 \pm 0.12$ & $0.632 \pm 0.002$ & $1.98 \pm 0.001$ \\
\hline
\end{tabular}




\begin{tabular}{|c|c|c|c|c|c|c|}
\hline 0.048 & $51.42 \pm 0.08$ & $92.58 \pm 0.01$ & $30 \pm 0.002$ & $29.44 \pm 0.054$ & $0.293 \pm 0.001$ & $0.171 \pm 0.004$ \\
\hline 0.01 & $35.05 \pm 0.08$ & $74.48 \pm 0.009$ & $10.56 \pm 0.001$ & $28.5 \pm 0.02$ & $0.239 \pm 0.012$ & $0.117 \pm 0.001$ \\
\hline $\mathrm{IC}_{50}(\mathrm{mg} / \mathrm{ml})$ & 1.126 & 0.9591 & $9.43 \pm 0.021$ & $7.58 \pm 0.12$ & $7.434 \pm 0.001$ & $34.656 \pm 0.009$ \\
\hline
\end{tabular}

\section{Total Flavonoids}

(Table 2) shows highly significant quantities of flavonoid contents in crude extracts of the two tested bacterial isolates. The highest level of total flavonoid content was observed in bacterial extract JX494761; although the contents of JX494759 crude extract were also high.It has been stated that the biological activities of Iraqi medicinal plants are related to the significantly higher flavonoid contents (TFC) as evidenced by the significantly positive correlation between the TFC and the inhibitory activity against $\beta$-glucuronidase enzyme [67]. Flavonoids, among other biologically active compounds such as sterols, alkaloids, saponins, glycosides, and tannins support the significant bioactivity exhibited by our crude extracts including inhibitory properties against a wide range of pathogens $[2-9,68]$. There is an increasing interest toward research on flavonoids occurring in various sources of marine organisms including sponges and their associated bacteria due to their multipurpose health benefits such as free-radical scavenging property, anticancer activity, antiviral properties,.....etc. [2-9].

\section{GC/MS Profiling for the Bacterial Crude Extracts}

The GC/MS analysis of crude bacterial extracts as shown in (Figure 4) indicates the presence of different bioactive components. The major components present in the ethyl acetate crude extracts are indicated in Table 3. The current study results revealed that the crude extract JX494761 contained the maximum diversity of identified compounds (8 compounds). Whereas extract JX494759 contained the lowest number of the identified compounds ( 5 compounds) as shown in Table 3. The bioactive composition of the two studied bacterial extracts obtained by GC/MS analysis and their bioactivity profiling are shown in Table 4 .

\section{FT-IR spectroscopy}

Results of FTIR spectroscopic studies have revealed the presence of various chemical constituents in ethyl acetate extracts of the ten bacterial isolates (Figure 5). The peak at 3412 and 2926 $\mathrm{cm}-1$ are corresponded to hydroxyl and $\mathrm{CH}$ stretching frequency respectively. A band at $1722 \mathrm{~cm}-1$ is corresponded to carbonyl carbon. The peak at $1631 \mathrm{~cm}-1$ to assign $\mathrm{C}=\mathrm{C}$. The strong peak at $2927.07 \mathrm{~cm}-1$ assigned to the $\mathrm{C}-\mathrm{H}$ stretching which means that some alkane compounds existed in these bacterial extracts. The bands between 3000 and $2800 \mathrm{~cm}-1$ represent $\mathrm{C}-\mathrm{H}$ stretching vibrations that are mainly generated by lipids. The stretching assigned to the C-S linkage occurs in the region at 700-600 Cm-1.

The weak absorption band of 601.79, 609.51, $707.88 \mathrm{Cm}-1$ indicates the presence of thiol sulphite and sulphate group in the extracts. The more intense bands occurring at 1635.64, 1722.43, $1722.42,1834.3,3412.08,1635.64$ corresponding to $\mathrm{C}=0$ stretching indicate the presence of ketones, aldehydes, carboxylic acids, esters and amide. The amide band are primarily associated with the stretching motion of the $\mathrm{C}=0$ group. This $\mathrm{C}=0$ band is sensitive to the environments of the peptide linkage and also depends on the protein's overall secondary structure.

\section{Elemental Analysis}

Elemental analysis of the tested extracts was presented in Table 5) The results of the elemental analysis of the ethyl acetate extract of the two tested bacteria isolates indicated that the bacterial the major elemental constituents in all living organisms; $\mathrm{C}, \mathrm{N}$ and $\mathrm{O}$. The results showed considerable concentrations of many halides (Cl, and Br). Extract JX494759 showed the highest concentration percentages of $\mathrm{Br}(18.013 \%), \mathrm{K}$ (10.190\%), whereas extract JX494761showed the highest concentrations of $\mathrm{Na}(0.953 \%)$ and $\mathrm{P}(0.513 \%)$ (Table 5$)$. It has been reported that many elements such as iron( $\mathrm{Fe})$, copper $(\mathrm{Cu})$, cobalt $(\mathrm{Co})$, nickel (Ni), zinc (Zn), manganese $(\mathrm{Mn})$, magnesium (Mg), molybdenum (Mo), chronium $(\mathrm{Cr})$, vanadium $(\mathrm{V})$, lithium (Li), selenium (Se), flourine $(\mathrm{F})$ and iodine (I) play both curative and preventive roles in fighting diseases of animals, plants and human beings [69] Kntapo et al. The tested bacterial extract HA-MS-23 had measurable concentration of $\mathrm{Mg}$. Mg is an essential activator for the phosphate-transferring enzymes myokinase, diphophospyridine nucleotide kinase, and creatine kinase. It also activates pyruvic acid carboxylase, pyruvic acid oxidase, and the condensing enzyme creatine kinase. It also activates pyruvic acid carboxylase, pyruvic acid oxidase, and the condensing enzyme for the reactions in the citric acid cycle.

It is also a constituent of bones, teeth, enzyme cofactor, kinases, etc. In the current study, among the various minerals potassium was observed in significantly high level in the JX494759 bacterial extract and in reasonable concentration in the JX494761extract. Without potassium which is an essential for the transport for nutrients inside the cell, nutrients could not be able to enter into the cell that leads cell death. Potassium is followed by phosphorous in the tested two extracts. Sodium, on the other hand, is the principle extracellular cation used for osmoregulation in inter modular fluid of human body was measured in the two tested extracts. The highest Na content was obtained from the JX494761bacterial isolate. Silicon which is also another important element to prevent the hardening blood veins and arteries was observed in the JX494761bacterial isolate, but not in the JX494759bacterial isolate. Al was measured in the JX494759 bacterial isolate, but not also in the JX494759 bacterial isolate. In the meantime, $\mathrm{Br}$ and $\mathrm{Cl}$ were found in the two bacterial extracts in different concentrations (Table 5). The presence of halogen substituents in many natural products profoundly influences their biological activity.

Chemical structures of marine products often differ from terrestrial secondary metabolites in being halogenated with bromine and/or chlorine. Chlorine is found in the JX494761bacterial extract. Unlike terrestrial organisms, marine organisms often produce halogenated secondary metabolites, particularly alkaloids [70]. The results of the current study showed that the highest bacterial extract in bromine content was JX494759. It has been suggested that marine life produces most of the 4,000 known natural organohalogens, and almost all of the 2,100 natural organobromine compounds are found in marine organisms [71]. 
Halogen containing secondary metabolites exhibit interesting biological effects, such as antibiotic, anticancer and others. On the other hand, Table 5 showed that the two tested bacterial extracts contained sulfur in variable amounts, among the highest bacterial extracts in sulfur contents was the JX494759bacterial isolate.

Sulfur in the form of organic and inorganic compounds is always present in all living organisms and is an important biogenic element. The average content of sulfur is relatively higher in marine organisms. On average natural product contain less nitrogen, sulfur, and halogen atoms but in marine natural product there is higher ratio of this constituent. Moreover, sulfur containing phenolic compounds can be reasonably speculated as strong antiinflammatory and antioxidant agents. Activity of sulfur-containing phenolic antioxidants in vivo is mediated by their effect on redoxsensitive transcription factors [87]. Conclusively, the presence of these elements in the tested extracts marks its usage in therapeutic purposes and may remark the tested bacterial extracts in the current study as promising bioactive materials.

\section{Biochemical Assays}

\section{Antioxidant Capacity}

Antioxidants are chemical substances used for treating various human diseases related to heart, lungs, kidney, muscle, brain and help to control aging process. Antioxidants effectively function in human body by inhibiting or delaying the formation of free radicals and lipid peroxidation that are mainly responsible for many human diseases and aging process. Free radicals are any chemical species capable of independent existence with one or more unpaired electrons in their outermost shell, which seek out and capture electrons from other substances to achieve neutrality. Although the initial attack causes the free radical to become neutralized, another free radical is formed in the process, resulting in a chain reaction. If two radicals meet they can combine their unpaired electrons, thus forming a covalent bond. Reactive oxygen species (ROS) refers to an array of metabolites derived from molecular oxygen $\left(\mathrm{O}_{2}\right)$.

These cellular renegades damage DNA, proteins, and lipids, altering biochemical compounds and corroding cell membrane. Such molecular mayhem plays a major role in the development of various diseases such as cancer, atherosclerosis, and respiratory ailments. The antioxidant capacity of compounds has been related to the prevention of several diseases including cancer, coronary heart diseases, inflammatory disorders, neurological degeneration, and aging [88]. Each in vitro antioxidant assay performed in this study evaluated the antioxidant activity of samples via a different mechanism. In the present study, antioxidant capacity of the bacterial extracts were measured using different in vitro methods, namely, DPPH, NO, Phosphomolybdenum and ABTS assays led to the evaluation of antioxidant potential of the studied bacterial extracts.

\section{DPPH Scavenging Activity}

In the present study, the antioxidant properties of the examined crude extracts, fractions were demonstrated on DPPH. DPPH scavenging activity in terms of $\mathrm{IC}_{50}$ values as compared to the standard (ascorbic acid) was shown to be relatively high in case of extracts JX494759 and JX494761 (1.126 and 0.9591 $\mathrm{mg} / \mathrm{ml}$, respectively) (Table 6). Phenolic compounds and other biologically compounds isolated from bacteria associated sponge t may be partially responsible for the radical scavenging activities of the crude extract and are mainly due to their redox properties, which can play an important role in absorbing and neutralizing free radicals, quenching singlet and triplet oxygen, or decomposing peroxides. It is known that the antioxidant activity of a compound is proportional to the number of hydroxyl groups it contains [89]. This probably explains the high radical scavenging activities of compounds JX494759 and JX494761 crude extracts [90].

\section{Nitric Oxide (NO) Assay}

The antioxidant properties of the examined crude extracts were also examined by using nitric oxide (NO) assay (Table 6). Antioxidants are capable of inhibiting the oxidation that produces free radicals. In turn, these radicals can start chain reactions that damage cells. Antioxidants terminate these chain reactions by removing free radicals intermediates, and inhibit other oxidation reactions [91] Chen et al. Under normal physiological Conditions, NO acts as a necessary component in the regulation of various physiological functions such as blood Pressure, immune response, and neural communication. However, overproduction of NO can induce tissue damage and is associated with inflammatory diseases including atherosclerosis and hypertension [92,93]. Therefore, researchers have paid more attention to discovering natural antioxidants that may act as potent inhibitors of NO production in relation to the treatment of chronic inflammatory diseases [92]. In nitric oxide free radical scavenging assay, highly significant percentage inhibition values were obtained for the studied crude extracts (Table 6). $\mathrm{IC}_{50}$ values of the antioxidant activity of bacterial extracts using NO assay were 9.43 and $7.58 \%$ for JX494759and JX494761crude extracts, respectively (Table 6). This may be attributed to the presence of phenolic compounds which have the potential to inhibit NO and peroxynitrite production [94], indicating that the presence of antioxidant molecules in all the tested crude extracts are responsible for their inhibitory effect [91].

\section{Phosphomolybdenum Assay}

In addition to the in vitro methods, DPPH, NO, and ABTS assays, phosphomolybdenum assay was also applied for led to the evaluation of antioxidant potential of the studied bacterial extracts. The results of the current study cleared out highly significant TEAC values were obtained in the examined bacterial extracts (Table 6). Addition of various concentrations of the extracts showed that extract JX494761 (34.656 $\pm 0.009 \mathrm{mM}$ equivalent ascorbic acid at extract concentration $30 \mathrm{mgml}$ ) was more effective to rduce Mo (VI) to Mo (V), while the lowest effects were shown by JX494759 (7.43 $\pm 0.001 \mathrm{mM}$ equivalent ascorbic acid at extract concentration 30 $\mathrm{mg} / \mathrm{ml}$ ). The reduction of Mo (VI) to Mo (V) suggested the presence of effective antioxidants in JX494761 bacterial extract. The highly significant antioxidant activities of the tested crude extracts are mainly due to the presence of biologically active compounds which an important role in improving human health. The compounds can decrease the risk of multiple chronic degenerative diseases, for instance gastrointestinal infection, cancer, Alzheimer, cataract and coronary heart disease. Polyphenolic compounds are among the interesting antioxidant compounds isolated from marine resources. 
It is understood that the intensity of the antioxidant activity of these complex polyphenols is related to the degree of polymerization of

\section{ABTS+ Assay}

Table 7: Total equivalent antioxidant activity and IC50 values of the bacterial extracts using ABTS+ assay.

\begin{tabular}{|c|c|c|c|}
\hline Extract no. & Conc. $(\mathbf{m g} / \mathbf{m l})$ & \% inhibition & mM Trolox equivalent $^{\text {IC }}$ (mg/ml) \\
\hline \multirow{5}{*}{ JX494759 } & 30 & 59.545 & 4.639 \\
\cline { 2 - 4 } & 6 & 49.673 & 3.536 \\
\cline { 2 - 4 } & 1.2 & 44.333 & 2.94 \\
\cline { 2 - 4 } & 0.24 & 44.657 & 2.976 \\
\cline { 2 - 4 } & 0.048 & 43.2 & 2.813 \\
\hline \multirow{5}{*}{ JX494761 } & 0.01 & 42.553 & 2.741 \\
\cline { 2 - 4 } & 30 & 92.883 & 4.766 \\
\cline { 2 - 4 } & 6 & 60.678 & 2.361 \\
\cline { 2 - 4 } & 1.2 & 39.154 & 1.837 \\
\cline { 2 - 4 } & 0.24 & 34.461 & 1.602 \\
\cline { 2 - 4 } & 0.048 & 32.357 & 1.566 \\
\hline
\end{tabular}

The results of the current study cleared out that the ABTS assay gave completely different results for the antioxidant activity measured in the tested two extracts (Table 7). The percentage inhibition of the JX494759 was much higher $\left(\mathrm{IC}_{50}=11.17 \mathrm{mg} / \mathrm{ml}\right)$ than that of the JX494761 extract $\left(\mathrm{IC}_{50}=3.831 \mathrm{mg} / \mathrm{ml}\right.$ ) revealing much higher antioxidant capacity.

\section{Anticancer assays}

\section{Cytotoxicity Against Cancer Cell Lines}

The tested crude extracts showed growth inhibition effects against the tested cell lines as shown in (Table 8). However, extract JX494759 showed a comparatively less cytotoxic activity against HepG2, HCT, and MCF-7. The present study results revealed the polyphenol. In general, lower degrees of polymerization result in greater antioxidant activities [95]. higher cell growth inhibitory effects of bacterial crude extracts against the tested cancer cell lines; HepG2; HCT and MCF-7 from extract JX494761. Throughout history, the cytotoxic actions of natural products have played a dominant role in identifying cancer chemotherapeutic drugs. It has been stated that Over $60 \%$ of the current anticancer drugs were derived in one way or another from natural sources [96]. In vitro cytotoxicity assays are a potentially useful tool in the study of toxic compounds of complex mixtures. To explore anticancer drugs from oceanic sources, many researchers have focused their attention on the secondary metabolites of marine micro-organisms. By means of cytotoxicity bioassay screening, many novel compounds that are potential candidate anticancer drugs have been isolated from marine micro-organisms for clinical applications since the beginning of this decade [97].

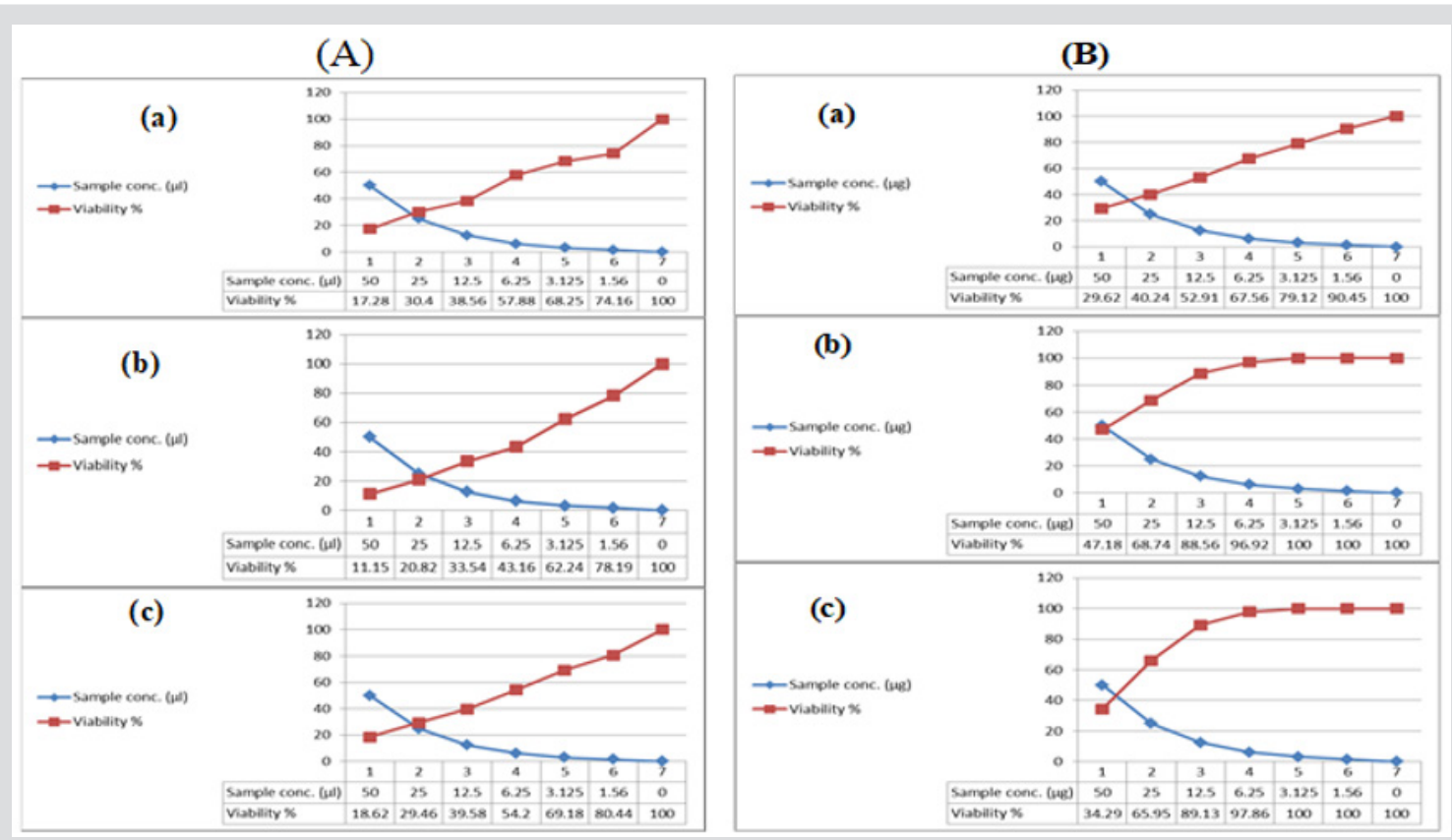

Figure 6: Cytotoxic activity of (A) JX494759 and (B) JX494761 extracts against cancer cell lines; (a): MCF-7, (b): HepG and (c): HCT. 
In the present study, the crude extracts of the examined bacterial isolates, each at six different concentrations $\left(\mathrm{IC}_{50}-1.56\right.$ $\mu \mathrm{g} / \mathrm{ml}$ ), were used to screen the cytotoxicity against breast cancer (MCF7), colon cancer (HCT) and hepatocellular carcinoma (HepG2). Cytotoxic effect of microbial crude extracts on cell viability of cancer cell lines was observed (Figure 6). The present study results are in agreement with previous findings; previous studies showed that there were some reports on Bacillus sp. (firmicutes) in producing some biologically active compounds against cancer cell lines [39]. Interestingly, the high cytotoxic effect of these extracts may be due to the presence of reasonable amounts of caffeic acid along with other biologically active compounds specially, alkaloids which have a strong anticancer effect in addition to the presence of Boron having biochemical and nutritional functions. More structural elucidation studies to be carried out on specifically on these two extracts due to its high potency to inhibit all types of the tested cancer cells at low concentrations; low $\mathrm{IC}_{50}$ values. Moreover, data obtained from cytotoxicity test against cancer cell lines are compatible with the high amounts of phenolic, flavonoids, alkaloids and other anticancer natural compounds in the tested extracts.

\section{Protein Kinase Inhibitory Effects}

Previous cytotoxicity results were confirmed by a specialized screening of anticancer test; protein kinase inhibition effect. Protein tyrosine kinase (PTK) is one of the major signaling enzymes in the process of cell signal transduction, which catalyzes the transfer of ATP- $\gamma$-phosphate to the tyrosine residues of the substrate protein, making it phosphorylation, regulating cell growth, differentiation, death and a series of physiological and biochemical processes [98]. The inhibitory effect of the bacterial extracts on universal PTK activity was measured and the results expressed as the mean of three samples \pm S.D. revealed that the inhibition activity of JX494759 was found to be relatively higher (inhibition \% = $94.44 \pm 1.24$ ) than that measured in case of JX494761 (inhibition $\%=76.85 \pm 1.03$ ) (Table 8). This may be due to the presence of the bioactive secondary metabolites specially alkaloids and other phenolic compounds such as Chlorogenic acid, Coffeic acid, and 3,5-Dicaffeoyl quinic acid which is in agreement with Ning et al., [99] who stated that marine sponge metabolites had proven to be extremely potent against a range of kinase targets heavily involved in an increasing list of disease mechanisms.

\section{Conclusion}

In conclusion, this study assessed the potential of microbial communities associated with marine sponges to produce bioactive natural compounds for the discovery and development of new drugs. Phylogenetic analyses of the isolated strains revealed the dominant groups as Firmicutes and Proteobacteria, , Two microbial isolates from the aforementioned phyla showed antioxidant activity as well as cytotoxicity against three established cancer cell lines revealing that the bacteria associated Red Sea sponge assayed could play an important source for the development of new biotechnological products. The active extracts deserve special attention in further studies on the isolation and structure elucidation, as well as more refined biological assays.

\section{Acknowledgment}

All the authors gratefully acknowledge Dr. Asmaa Nabiel Adam and Mr. Mohamed Adel from the National Institute of Oceanography and Fisheries, Egypt for their help and technical support. The authors also acknowledge with thanks Prof. Rob. W. M. van Soest, at the Institute for Systematic and Ecology, the University of Amsterdam, Netherlands for his help in identification of the sponge specimen.

\section{References}

1. Hentschel U, Schmid M, Wagner L, Fieseler C Gernert, J Hacker (2001) Isolation and phylogentic analysis of bacteria with antimicrobial activities from the Me diterranean sponges Aplysina aerophoba and Aplysina cavernicola. FEMS Microbiology Ecology; 35(3): 305-312.

2. Abdel Moniem NM, Yacout GA, Aboul Ela HM (2017) Hepatoprotective Activity of Chitosan Nanocarriers Loaded With the Ethyl Acetate Extract of Astenotrophomonas sp. Bacteria Associated with the Red Sea Sponge Amphimedon Ochracea In CCl4 Induced Hepatotoxicity in Rats. Advances in Bioscience and Biotechnology 8(1): 27-50.

3. Abdel Moniem NM, Al Assar SA, Shreadah MA (2017) Isolation, Identification and Molecular Screening of Psudomance Sp Metabolic pathways NRPs and PKS associated with the Red Sea sponge, Hyrtios aff. erectus, Egypt. Journal of pure \& Applied Microbiology 11(3): 12991311.

4. Abdel Moniem NM, Sheradah MA, Al Assar SA (2017) Protective role of antioxidant capacity of Hyrtios aff. erectus sponge extract against mixture of Persistent organic pollutant (POPs)-induced hepatic toxicity in liver mice: Biomarkers and Ultra-structural study. Environmental Science and Pollution Research 24(27): 22061-22072.

5. Abdel Moneim NM, Al Assar SA, Shreadah MA (2018) The hepatoprotective effect of Hyrtios aff. Erectus sponge isolated from the Red sea extract against the toxicity of Persistent organic pollutants (POPs) from Sediments of Lake Mariout. Journal Biotechnology and Biotechnological Equipment 32(3): 734-743.

6. Sheradah MA, Abdel Moniem NM, Al-Assar SA (2017) The Ameliorative Role of a Marine Sponge Extract against Mixture of Persistent Organic Pollutants induced Changes in Hematological Parameters in Mice. Expert Opinion Environmental Biology 6(2).

7. Shreadah MA, Abdel Moniem NM, Al Assar SA e, and Asmaa Nabil Adam (2018a) Phytochemical and pharmacological screening of Sargassium vulgare from Suez Canal, Egypt. Food Science and Biotechnology 27(4): 963-979.

8. Shreadah MA, Abdel Moniem NM, Yakout G, Abo Ella HM (2018b) Bacteria from Marine Sponges: A Source of Biologically Active Compounds. Biomedical Journal of Scientific \& Technical Research 10(5): 1-20.

9. Shreadah MA, Abdel Moniem NM, Yakout G, Abo Ella HM (2018c) Isolation, Phylogenetic Analysis of the Microbial Community Associated with the Red Sea Sponge Ircinia Echinata and Biological Evaluation of their Secondary Metabolites. Biomedical Journal of Scientific \& Technical Research 12 (2): 1-19.

10. Jackson SA, Kennedy J, Morrissey JP, O Gara F, Dobson ADW (2012) Pyrosequencing Reveals Diverse and Distinct Sponge-Specific Microbial Communities in Sponges from a Single Geographical Location in Irish Waters. Microbial ecology 64(1): 105-116.

11. Taylor MW, Radax R, Steger D, Wagner M 2(007) Sponge-associated microorganisms: evolution, ecology, and biotechnological potential. Microbiology and molecular biology reviews 71(2): 295-347.

12. Kefalas E, Castritsi Catharios J, Miliou H (2003) Bacteria associated with the sponge Spongia officinalis as indicators of contamination. Ecological Indicators 2(4): 339-343. 
13. Kikuchi S, Okada K, Cho Y, Yoshida S, Kwon E, et al. (2018) Isolation and structure determination of lysiformine from bacteria associated with marine sponge Halichondria okadai. Tetrahedron 74(27):3742-3747.

14. Jeganathan P, Rajasekaran KM, Devi ANK, Karuppusamy S (2013) Antimicrobial activity and characterization of marine bacteria. Indian Journal of Pharmaceutical and Biological Research 1(4): 38-44.

15. Yoghiapiscessa D, Batubara I, Wahyudi AT (2016) Antimicrobial and Antioxidant Activities of Bacterial Extracts from Marine Bacteria Associated with Sponge Stylotella sp. American Journal of Biochemistry and Biotechnology 12(1): 36-46.

16. Mehbub MF, Lei J, Franco C, Zhang W (2014) Marine sponge derived natural products between 2001 and 2010: trends and opportunities for discovery of bioactives. Marine Drugs 12(8): 4539-4577.

17. Nazim K, Sherwani SK, Khan MU, Kausar R, Rizvi G (2014) Antibacteria activity of marine sponge collected from Sunhari Beach. FUUAST Journal of Biology 4(2): 233-236.

18. Elkomy RG, Ibraheem IB, Shreadah MA, Mohammed R (2015) Optimal Conditions for Antimicrobial Activity Production from Two Microalgae Chlorella marina and Nevicula F. delicatula. Journal of Pure and Applied Microbiology 9(4): 2725-2732.

19. Elkomy RG, Ibraheem IB, Shreadah MA, Mohammed R, Ismael AA (2015) Antibacterial and Antifungal Activity of Three Microalgae Isolated from Egyptian Coast of the Mediterranean Sea. Journal of Pure and Applied Microbiology 9(4): 2751-2758.

20. Pereira SV, Parvatkar P, Furtado IJ (2015) Evaluation of antioxidant producing potential of halophilic bacterial bionts from marine invertebrates. Indian Pharmaceutical Sciences 77: 183-189.

21. Shriadah MA, Okbah MA, El-Deek MS (2004) Trace metals in the wate columns of the Red Sea and the Gulf of Aqaba, Egypt. Water, Air and Soil Pollution; 153(1-4): 115-124.

22. Okbah MA, Shata MA, Shriadah MA (2005) Gochemical forms of trace metals in mangrove sediments-Red Sea (Egypt). Chemistry and Ecology 21(1): 23-36.

23. Shreadah MA, Masoud MS, Said TO (2008a) Application of IR, X-Ray, TGA and DTA to determine the mineral composition of the Sediments and study of reaction kinetics along the Egyptian Red Sea Coasts. Egyptian Journal of Aquatic Research 34(4): 83-95.

24. Shreadah MA, Said TO, Abd El Ghani SA (2008b) Alkyl lead and Alkyltin species in different fishes collected from the Suez Gulf, Egypt. Proceedings of the 2 nd International conference on aquatic res. Egyptian Journal of Aquatic Research 34(4): 64-73.

25. Shreadah MA, Said TO, El Zokm GM (2008c) Physico-chemical characterititics of the surficial sediments along the Egyptian Red Sea coasts. Egyptian Journal of Aquatic Research 34(4): 16-34

26. Shreadah MA, Masoud MS, Said TO (2008d) Application of IR, X-Ray, TGA and DTA to determine the mineral composition of the Sediments and study of reaction kinetics along the Egyptian Red Sea Coasts. Egyptian Journal of Aquatic Research 34(4): 16-34.

27. Shreadah MA, Said TO, Abdel Ghani SA (2011) Distribution of Differen Organotinand Organolead Compounds in Sediment of Suez Gulf. Journal of Environmental Protection 2(5): 545- 554.

28. Gurguess SM, Shreadah MA, Fahmy MA, Aboul El Kheir E, Abdel Halim AM (2009) Assessment of water quality in the Red Sea using in situ measurements and remote sensing data. Egyptian Journal of Aquatic Research 35(2): 1-13.

29. Fahmy MA, Shriadah MA, AbulSoud A, Abdel Rahman SM, Shindy M (2005) Hydrography and Chemical Characteristics of the Coastal Water along the Gulf of Suez. Egyptian Journal of Aquatic Research 31: 1-14.

30. Fahmy MA, Abdel Fattah LM, Abdel-Halim AM (2016) Evaluations of the Coastal Water Quality of the Egyptian Red Sea during 2011-2013. Journal of Environmental Protection 7: 1810-1834.

31. Abo El khair EM, Abdel Halim AM, Shriadah MA, Fahmy MA (2007) Environmental Conditions of the Suez Gulf and the Red Sea Coastal Waters, Egypt. Proceedings of the 8thInternational Conference on the
Mediterranean Coastal Environment. MEDCOAST 2007. E Ozhan (Eds.). 13-17.

32. Abo El khair EM, Abdel Halim AM, Fahmy MA, Shriadah MA (2008) Environmental Impact Assessment of Northern Red Sea Regions during 2005-2007. Egyptian Journal of Aquatic Research 34(2): 20-30.

33. Abo El khair EM, Abdel Fattah LM, Abdel Halim AM, Abdel Nabi MA, Fahmy MA, et al. (2016) Assessment of the hydrochemical characteristics for the coastal waters of the Suez Gulf during 2011-2013. Journal of Environmental Protection 7(11): 1497-1521.

34. Abdel Halim AM, Abo El Khair EM, Fahmy MA (2007) Environmental Assessment on the Aqaba Gulf Coastal waters, Egypt. Egyptian Journal of Aquatic Research 33(1): 1-14.

35. Abdel Halim AM, Abdel Nabi MA, Abdel Fattah LM (2016) Environmental studies on the Aqaba Gulf coastal waters during 2011-2013. Journal of Environmental Protection 7(10): 1411-1437.

36. Said TO, Shreadah MA, Abdel Ghani SA, Ahmed AM (2010) Alkyltin and alkaylleadcompounds in coastal water of Suez Gulf, Egypt. Egyptian Journal of Aquatic Research 36(1): 33-42.

37. Masoud MS, Said TO, El Zokm G, Shreadah MA (2010) Speciation of Fe, $\mathrm{Mn}$ and $\mathrm{Zn}$ in Surficial Sediments from the Egyptian Red Sea Coasts. Chemical Speciation and Biodiversity 22(4): 257-269.

38. Masoud MS, Said TO, El- Zokm G, Shreadah MA (2012) Assesment of Heavy Metals Contamination in Surface Sediments of the Egyptian Red Sea Coasts. Asturalian Journal of Basic and Applied Sciences 6: 44-58.

39. Aboul Ela MH, Shreadah MA, Abdel Moniem NM, Yakout GA, Van Soest RWM (2012) Isolation, cytotoxic activity and phylogenetic analysis of Bacillus sp. bacteria associated with the red sea sponge Amphimedonochracea. Advances in Bioscience and Biotechnology 3 (7): 815-823.

40. Hegazy MF, Mohamed TA, Elshamy A MI, Hassanien AA, Abdel Azimd NS, et al. (2015a) A New Steroid from the Red Sea Soft Coral Lobophytum Lobophytum. Natural Products Research; 30(3): 340-344.

41. Hegazy MF, Gamal Eldeen AM, Mohamed TA, Alhammady MA, Hassanien AA, Set al. (2015b) Cytotoxic Constituents from the Red Sea Soft Coral Nephthea Sp., Natural Products Research 30: 1266-1272.

42. Abdel Tawab AM, Fayad W, Shreadah MA, Nassar MI, Abou Elzahab MM, etal. (2018) GC/MS Identification and biological evaluation of the Red sea soft coral Nephthea molle extracts. Research Journal of Pharmaceutical Biological and Chemical Sciences 9(3): 595-602.

43. Segall RM, Colwell RR (1985) Characterization of a marine bacterium associated with Crassostrea virginica (the eastern oyster). Applied and Environmental Microbiology 49(1): 83-90.

44. Shirling EB, Gottlieb D (1966) Methods for characterization of Streptomyces species. International Journal of Systematic Bacteriology 16: 313-340.

45. Webster NS, Hill RT (2001) The culturable microbial community of the Great Barrier Reef sponge Rhopaloeides odorabile is dominated by an alphaproteobacterium. Marine Biology 138(4): 843-851.

46. Sambrook J, Fritsch EF, Maniatis T (2001) Molecular Cloning. (4 $4^{\text {th }}$ edn.), A Laboratory Manual, Cold Spring Harbor Laboratory Press New York, USA.

47. Acinas SG, Anton J, Rodriguez Valera F (1999) Diversity of free-living and attached bacteria in offshore western Mediterranean waters as depicted by analysis of genes encoding $16 \mathrm{~S}$ rRNA. Applied and Environmental Microbiology 65(2): 514-522.

48. Weisburg WG, Barns SM, Pelletier DA, Lane DJ (1991)16S ribosoma DNA amplification for phylogenetic study. Journal of Bacteriology 173(2): 697-703.

49. Thanomsub B, Poomeechockchai W, Limtrakul A, Arunrattiyakorn P, Petchleelaha W, et al. (2006) Withdrawn: Chemical structures and biological activities of rhamnolipids produced by Pseudomonas aeruginosa B189 isolated from milk factory waste. Bioresource Technology 98(5): 1149-1153. 
50. Tamura K, Peterson D, Peterson N, Stecher G, Nei M, et al. (2011) MEGA5: Molecular Evolutionary Genetics Analysis using Maximum Likelihood, Evolutionary Distance, and Maximum Parsimony Methods. Molecular Biology and Evolution 28(10): 2731-2739.

51. Wiley RA, Rich DH (1993) Peptidomimetics derived from natural products. Medicinal research reviews 13(3): 327-384.

52. Taga MS, Miller EE, Pratt DE (1984) Chia seeds as a source of natural lipid antioxidants. Journal American Oil Chemical Society 61(5): 928931.

53. Zhishen J, Mengcheng T, Jianming W (1999) Research on antioxidant activity of flavonoids from natural materials. Food Chemistry 64: 555559.

54. Mosmann T (1983. Rapid colorimetric assay for cellular growth and survival: application to proliferation and cytotoxicity assays. Journal of Immunology Methods 65(1-2): 55.

55. Vijayan P, Raghu C, Ashok G, Dhanaraj SA, Suresh B (2004) Antiviral activity of medicinal plants of Nilgiris, Indian Journal of Medicinal Research 120(1): 24-29.

56. Green LC, Wagner DA, Glogowski J, Skipper PL, Wishnok JK, et al (1982) Analysis of nitrate, nitrite and $15 \mathrm{~N}$ in biological fluids. Analytical Biochemistry 126(1): 131-136.

57. Blois MS (1958) Antioxidant determination by the use of stable free radicals. Nature 181: 1199-2000.

58. Amarowicz R, Pegg RB, Bautista DA (2000b) Antibacterial activity of green tea polyphenols against Escherichia coli K12. Nahrung 44(1): 6062

59. Shirwaikar A, Shirwaikar A, Kuppusamy R, Isaac SR (2006) In Vitro Antioxidant Studies on the Benzyl Tetra Isoquinoline Alkaloid Berberine. Biological and Pharmaceutical Bulletin 29(9): 1906-1910.

60. Bibi F, Faheem M, Azhar EI, Yasir M, Alvi SA, et al. (2017) Bacteria From Marine Sponges: A Source of New Drugs. Current Drug Metabolism 18(1): 11-15

61. Christensen A, Martin GDA (2017) Identification and bioactive potential of marine microorganisms from selected Florida coastal areas. Microbiology Open 6(4): 1-10.

62. Anantharaju PG, Gowda PC, Vimalambike MG, Madhunapantula SV (2016) An overview on the role of dietary phenolics for the treatment of cancers . Nutrition Journal 15(1): 99-115.

63. Akomolafe SF, Akinyemi AJ, Anadozie So (2014) Phenolic Acids (Gallic and Tannic Acids) Modulate Antioxidant Status and Cisplatin Induced Nephrotoxicity in Rats. International Scholarly Research Notices. 984709: 8 pages.

64. Zhang J, Sun Z, Sun P, Chen T, Chen F (2014) Microalgal carotenoids: Beneficial effects and potential in human health. Food Function 5(3): 413-425.

65. Fiedor J, Burda K (2014) Potential role of carotenoids as antioxidants in human health and disease. Nutrients 6(2): 466-468.

66. Torregrosa Crespo J, Montero Z, Fuentes ZL, García Galbis MR, Garbayo I, et al. (2018) Exploring the Valuable Carotenoids for the Large-Scale Production by Marine Microorganisms. Marine Drugs 16(6): 203-228.

67. Molan A, Mahdy AS (2014) Iraqi medicinal plants: Total flavonoid contents, free-radical scavenging and bacterial beta-glucuronidase inhibition activities. Journal of Dental and Medical Sciences 13(5): 72 77.

68. Dhayalan A, Gracilla DE, Dela Peña Jr RA, Malison MT, Pangilinan CR (2018) Phytochemical Constituents and Antimicrobial Activity of the Ethanol and Chloroform Crude Leaf Extracts of Spathiphyllum cannifolium (Dryand. ex Sims) Schott. Journal of Pharmacy and Bioallied Sciences 10(1): 15-20.

69. Kntapo FM, Salisu AG, Said RM (2018) X-Ray flourescence (XRF) elemental composition of Euphorbia hirta Linn (Asthma weed) as a medicinal plant. Asian Journal of Medical and Biological Research 4 (1): 49-54

70. Dembitsky VM, Srebnik M (2002) Natural halogenated fatty acids: their analogues and derivatives. Progress Lipid Research 41(4): 315-367.

71. Pauletti PM, Cintra LS, Braguine CG, da Silva Filho AA, Silva MLA, et al. (2010) Halogenated Indole Alkaloids from Marine Invertebrates. Marine Drugs 8(5): 1526-1549.

72. Yang C, Chen H, Chen H, Zhong B, Luo X, Chun J (2017) Antioxidant and Anticancer Activities of Essential Oil from Gannan Navel Orange Peel. Molecules 22(8): 1391-1401.

73. Al Marzoqi AH, Hameed IH, Idan SA (2015) Analysis of bioactive chemical components of two medicinal plants (Coriandrum sativum and Melia azedarach) leaves using gas chromatography-mass spectrometry (GC-MS). African Journal of Biotechnology 14(40): 2812-2830.

74. De Sousa D P (2015) Bioactive essential oils and cancer. Springer International publishing AG.

75. Babu A, Noor S, Mohamed M, Jaikumar K, Anand D, et al. (2017) In vitro Anti-Helicobacter pylori Activity and GC-MS Analysis of Enicostemma axillare (Lam). International Journal of Pharmaceutical Sciences and Drug Research. 9(3): 100-104.

76. Tunon H, Thorsell W, Bohlin L (1993) Mosquito Repelling Activity of Compounds Occurring in Achillea millefolium L. (Asteraceae). Economic Botany 48(2): 111-120.

77. Menezes AMS, Almeida FRC, Rao VSN, Matos MEO (1990) Antiinflammatory activity of the essential oil of Vanillosmopsis arborea. Fitoterapia 61(3): 252-254.

78. Friedman M (1997) Chemistry, Biochemistry, and Dietary Role of Potato Polyphenols. A Review. Journal of Agricultural and Food Chemistry 45 (5): 1523-1540.

79. Lucas GHW, Henderson VE (1929) A new anasthetic gas: cyclopropane, a preliminary report Can Med Assoc J 21(2): 173-175.

80. Chen Y, Mc Carthy PJ, Harmody DK, Schimoler O'Rourke R, Chilson K, et al. (2002) New bioactive peroxides from marine sponges of the family plakiniidae. J Nat Prod 65(10): 1509-1512.

81. Rudi A, Afanii R, Gravalos LG, Aknin M, Gaydou E, et al. (2003) Three new cyclic peroxides from the marine sponge Plakortis aff simplex. Journal of Natural Products 66(5): 682-685.

82. Al Wabli RI, Al Ghamdi AR, Ghabbour HA, Attia MI (2017) Crystal structure of 1-(2H-1,3-benzodioxol-5-yl)-3- (1H-imidazol-1-yl)propan1-one, C13H12N2O3. Z. Kristallogr. NCS 232(3).

83. Attia MA, Ghabbour HA, Almutairi MS, Ghoneim SW, Hoong Kun Fun H (2015) Single-Crystal X-ray Structure of the Anti-Candida Agent, (E)-3(1H-Imidazol-1-yl)-1-phenylpropan-1-one 0-3-Chlorobenzoyl Oxime. Tropical Journal of Pharmaceutical Research 14(10): 1865-1870.

84. DongY, Liao J, Yao K, Jiang W, Jie Wang J (2017) Application of Traditional Chinese Medicine in Treatment of Atrial Fibrillation. Evidence-Based Complementary and Alternative Medicine 1381732: 11.

85. Varro A, Biliczki P, Iost N, Virag L, Hala O, et al. (2004) Theoretical possibilities for the development of novel antiarrhythmic drugs. Current Medicinal Chemistry 11(1): 1-11.

86. Dallmeier K, Carlini EA (1981) Anesthetic, Hypothermic, Myorelaxant and Anticonvulsant Effects of Synthetic Eugenol Derivatives and Natural Analogues. Pharmacology 22(2): 113-127.

87. Zenkov NK, Menshchikova EB, Kandalintseva NV, Oleynik AS, Prosenko $\mathrm{AE}$, et al. (2007) Antioxidant and anti-inflammatory of new watersoluble sulfur containing phenolic compounds. Biochemistry(Moscow) 72(6): 644-651.

88. Balakrishnan D, Kandasamy D, Nithyanand P (2014) A review on Antioxidant activity of marine organisms. International Journal of ChemTech Research CODEN (USA) 6(7): 3431-3436 
89. Simić A, Manojlović D, Šegan D, Todorović M (2007) Electrochemical behavior and antioxidant and prooxidant activity of natural phenolics. Molecules 12(10): 2327-2340.

90. Njateng GSS, Du Z, Gatsing D, Mouokeu RS, Liu Y, et al. (2017) Antibacterial and antioxidant properties of crude extract, fractions and compounds from the stem bark of Polyscias fulva Hiern (Araliaceae). BMC Complementary and Alternative Medicine 17(1): 99.

91. Chen H, Lan X, Wu Y, Ou Y, Chen TC, et al. (2017) The antioxidant activity and nitric oxide production of extracts obtained from the leaves of Chenopodium quinoa Willd. Biomedicine (Taipei) 7(4): 24.

92. Pacher P, Beckman JS, Liaudet L (2007) Nitric oxide and peroxynitrite in health and disease. Physiological Reviews 87(1): 315-424.

93. Taira J, Nanbu H, Ueda K (2009) Nitric oxide-scavenging compounds in Agrimonia pilosa Ledeb on LPS-induced RAW264.7 macrophages. Food Chemistry 115(4): 1221-27.

94. Conforti F, Menichini F(2011) Phenolic compounds from plants as nitric oxide production inhibitors. Current Medicinal Chemistry 18(8): 1137 1145 .

\section{ISSN: 2574-1241}

DOI: 10.26717/BJSTR.2019.15.002682

Shreadah MA. Biomed J Sci \& Tech Res

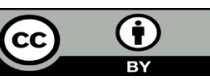

This work is licensed under Creative Commons Attribution 4.0 License

Submission Link: https://biomedres.us/submit-manuscript.php
95. Bonnefont Rousselot D (2016) Resveratrol and Cardiovascular Diseases. Nutrients 8(5): 250

96. Iqbal I, Abbasi BA, Mahmood T, Kanwal S, Ali B, et al. (2017) Plantderived anticancer agents: A green anticancer approach. Asian Pacific Journal of Tropical Biomedicine 7(12): 1129-1150.

97. Graziani V, Scognamiglio M, Belli V, Esposito A, D Abrosca B, et al. (2018) Metabolomic approach for a rapid identifcation of natural products with cytotoxic activity against human colorectal cancer cells. Scientific Reports 8: 5309.

98. Jiao Q, Bi L, Ren Y, Song S, Wang Q, et al. (2018) Advances in studies of tyrosine kinase inhibitors and their acquired resistance. Molecular Cancer 17: 36

99. Ning C, Wang HD, Gao R, Chang YC, Hu F, et al. (2018) Marine-derived protein kinase inhibitors for neuroinflammatory diseases. Biomedical Engineering 17(1): 46.

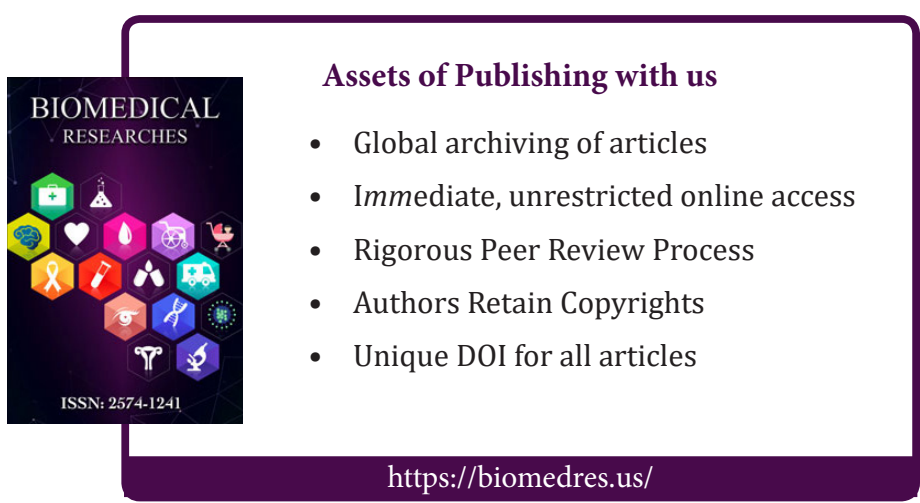

